\title{
Mixed-Generation PAMAM G3-G0 Megamer as a Drug Delivery System for Nimesulide: Antitumor Activity of the Conjugate Against Human Squamous Carcinoma and Glioblastoma Cells
}

\author{
Magdalena Zaręba ${ }^{1}$, Przemysław Sareło ${ }^{2}{ }^{\circ}$, Marta Kopaczyńska ${ }^{2}$, Agata Białońska ${ }^{3}$, \\ Łukasz Uram ${ }^{1}\left(\mathbb{D}\right.$, Małgorzata Walczak ${ }^{1} \mathbb{D}$, David Aebisher ${ }^{4}$ and Stanisław Wołowiec ${ }^{4, *}$ (D) \\ 1 Faculty of Chemistry, Rzeszów University of Technology, 35-939 Rzeszów, Poland; \\ magzar@prz.edu.pl (M.Z.); luram@prz.edu.pl (Ł.U.); mwalczak@prz.edu.pl (M.W.) \\ 2 Department of Biomedical Engineering, Wrocław University of Science and Technology, \\ 50-370 Wrocław, Poland; przemyslaw.sarelo@pwr.edu.pl (P.S.); marta.kopaczynska@pwr.edu.pl (M.K.) \\ 3 Faculty of Chemistry, University of Wrocław, 50-383 Wrocław, Poland; agata.bialonska@gmail.com \\ 4 Centre for Innovative Research in Medical and Natural Sciences, Faculty of Medicine, University of Rzeszów, \\ 35-310 Rzeszów, Poland; daebisher@ur.edu.pl \\ * Correspondence: swolowiec@ur.edu.pl; Tel.: +48-604505241
}

Received: 13 September 2019; Accepted: 8 October 2019; Published: 9 October 2019

\begin{abstract}
Polyhydroxylated dendrimer was synthesized from poly(amidoamine) (PAMAM) dendrimer generation 3 by addition of glycidol $\left(\mathrm{G}^{\mathrm{gl}}\right)$. $\quad \mathrm{G}^{\mathrm{gl}}$ megamer was further modified by binding PAMAM G0 dendrimers by activation of G3 ${ }^{\mathrm{gl}}$ with $p$-nitrophenylchloroformate, followed by the addition of excess PAMAM G0 and purification using dialysis. The maximum G0 binding capacity of $\mathbf{G}^{\mathrm{gl}}$ was 12 in the case when G0 was equipped with two covalently attached nimesulide equivalents. Nimesulide (N) was converted into $\mathrm{N}$-( $p$-nitrophenyl) carbonate derivative and fully characterized using X-ray crystallography and spectral methods. Nimesulide was then attached to $\mathrm{G} 0$ via a urea bond to yield $\mathrm{G}^{2 \mathrm{~N}}$. The mixed generation $\mathrm{G} 3^{\mathrm{gl}}-\mathrm{G}^{2 \mathrm{~N}}$ megamer was characterized using ${ }^{1} \mathrm{H}$ NMR spectroscopy, and its molecular weight was estimated to be $22.4 \mathrm{kDa}$. The AFM image of $\mathbf{G}^{\mathrm{gl}}-\mathrm{G}^{\mathbf{2 N}}$ deposited on mica demonstrated aggregation of nimesulide-covered megamer. The height of the deposited megamer was $8.5 \mathrm{~nm}$. The megameric conjugate with nimesulide was tested in vitro on three human cell lines: squamous cell carcinoma (SCC-15) and glioblastoma (U-118 MG) overexpressing cyclooxygenase-2 (COX-2), and normal skin fibroblasts (BJ). The conjugate efficiently penetrated into all cells and was more cytotoxic against SCC-15 than against BJ. Moreover, the conjugate produced a strong and selective antiproliferative effect on both cancer cell lines $\left(\mathrm{IC}_{50}<\right.$ $7.5 \mu \mathrm{M})$.
\end{abstract}

Keywords: drug delivery system; PAMAM megamer; nimesulide conjugate; anticancer activity

\section{Introduction}

Nonsteroidal anti-inflammatory drugs (NSAID) are used for treatment of pain and inflammation [1]. Some of them, like celecoxib (C) or nimesulid (N) are selective or preferential cyclooxygenase-2 (COX-2) inhibitors. Over-expression of COX-2 has been detected in a variety of human tumors in breast, prostate, lung, skin and colon, and therefore, $\mathbf{C}$ and $\mathbf{N}$ are currently being tested for anticancer activity [2].

Side effects that can occur during long-term oral administration of NSAID include gastrointestinal irritation, ulcers, and impairment of renal blood circulation and glomerulic filtration. These adverse effects can be avoided by blood administration of $\mathbf{C}$ and $\mathbf{N}$ attached to a macromolecular carrier. 
We have followed the enhanced permeation and retardation (EPR) strategy and recently tested $\mathrm{C}$ and F-Moc-L-Leucine (L), the PPAR- $\gamma$ agonist attached to third generation polyamidoamine dendrimer (PAMAM G3), in vitro for cytotoxicity against the cancer lines glioblastoma (U-118 MG) and squamous cell carcinoma (SCC-15). We found that the biotinylated conjugate bearing both $\mathbf{C}$ and $\mathbf{L}$ showed additive cytotoxicity for fibroblasts and both cancer lines in order BJ $>$ U-118 MG $>$ SCC-15, with $\mathrm{IC}_{50}$ in the range $0.69,1.44$ and $2.22 \mu \mathrm{M}$, respectively [3]. In addition, we also applied biotinylated PAMAM G3 as carrier of $\mathbf{N}$ [4]. The bioconjugates $\mathbf{G}^{\mathbf{N}}$ bearing 18 or $31 \mathbf{N}$ exerted selective toxic effect on SCC-15 cells but not against normal human fibroblasts (BJ) at low range of concentration $(1.25-10 \mu \mathrm{M})$ with 250 fold stronger action than native nimesulide. Moreover, this conjugates induced apoptotic cell death via COX-2/PGE 2 independent pathway.

Full generation PAMAM dendrimers are systematically toxic; therefore, surface amine group modification by PEG-ylation [5], hydroxylation with D-glucoheptono-1,4-lactone [6] or hydroxyalkylation with glycidol is often explored to reduce the systemic toxicity of carrier.

On the other hand, amine groups of full generation PAMAM dendrimers are convenient sites for linking drug molecules or combinations of drugs, targeting molecules like biotin, folate and others.

PAMAM dendrimers can be stored in methanol at low temperatures, nonetheless, after several months, spontaneous aggregation of pristine dendrimers is observed [7]. The aggregation can be performed efficiently under chemical control using an appropriate linker, like glutaraldehyde [8,9], cyclooctyne-azide click coupling [10], or a straightforward reaction between variably terminated dendrimers, like $\mathrm{G} 2-\mathrm{COOH}$ and $\mathrm{G} 2-\mathrm{NH}_{2}[7,11]$. The stoichiometry and aggregation level in these procedures cannot be strictly controlled; therefore, high molecular weight dispersion of megamers is an inevitable feature.

We began our contribution to the field by using regular PAMAM G3 dendrimer as carrier of retinal, biotin and pyridoxal for transdermal delivery $[12,13]$ and later applied them as carriers for anticancer drugs [3]; glucoheptoamidated PAMAM G3 dendrimer was shown to be an effective carrier for doxorubicin $[6,14]$.

Encouraged by the results on the selective and efficient anticancer activity of PAMAM G3 ${ }^{\mathrm{N}}$ conjugates, we synthesized a new macromolecular carrier for $\mathbf{N}$, comprised of hydroxylated PAMAM G3 with covalently bound PAMAM G0 dendrimers substituted with $\mathbf{N}$. In this way, we obtained a very well water soluble megameric conjugate and tested it for cytotoxicity against human squamous carcinoma (SCC-15) and glioblastoma cells (U-118 MG), and comparatively against normal human fibroblasts (BJ).

\section{Results and Discussion}

\subsection{Chemistry}

\subsubsection{Reaction of PAMAM Dendrimers with Glycidol}

2,3-Epoxypropanol (glycidol, $\mathbf{g l}$ ) is an oxirane which undergoes facile reaction with amine groups. The addition leads to gl epoxide ring opening and doubles the number of free hydroxyl groups. Therefore, gl found application in obtaining water-soluble oligoetherols from 1,3,5-triazine or barbituric acid, which were further used to obtain polyurethane foams with improved thermal resistance [15].

We have used $\mathbf{g}$ to convert PAMAM G3 dendrimer into a completely hydroxyalkylated derivative, which remained water soluble like starting G3 and has no free primary amine groups. In order to establish the protocol for this conversion, we present a synthetic path starting from PAMAM G0. We found that eight molecules of $\mathbf{g l}$ are added within two days of reaction with $\mathbf{G} \mathbf{0}$ at room temperature to give the yellow oily product $\mathbf{G}^{\mathrm{gl}}{ }^{\mathrm{l}}$ (Scheme 1 ). The progress of reaction was monitored using ${ }^{1} \mathrm{H}$ NMR spectroscopy. The spectra of substrates $\mathbf{g l}$ and $\mathbf{G 0}$ are presented at Figure 1 (traces A and B, respectively). Large magnetic non-equivalence of both a and $\mathrm{c}$ methylene groups vicinal to chiral carbon $\mathrm{b}$ in $\mathbf{g l}$ (trace A) is almost cancelled after ring opening and addition of $\mathbf{g} \mathbf{1}$ to G0. The largest chemical shift (0.5 ppm downfield) occurs for the $\mathrm{H}_{\mathrm{b}}$ proton upon conversion from $\mathrm{gl}$ into 1,2-dihydroxypropyl 
group in $\mathbf{G}^{\mathbf{g l}}$. The $\mathrm{H}_{7}$ resonance of $\mathbf{G} 0$ resonances is also shifted $0.1 \mathrm{ppm}$ downfield upon addition of two $\mathbf{g l}$ onto the terminal nitrogen atom of $\mathrm{G0}^{\mathbf{g l}}$ (trace $\mathrm{C}$ versus $\mathrm{B}$ ).



Scheme 1. Conversion of polyamidoamine (PAMAM) G0 dendrimer to G0gl by addition of eight glycidol equivalents.
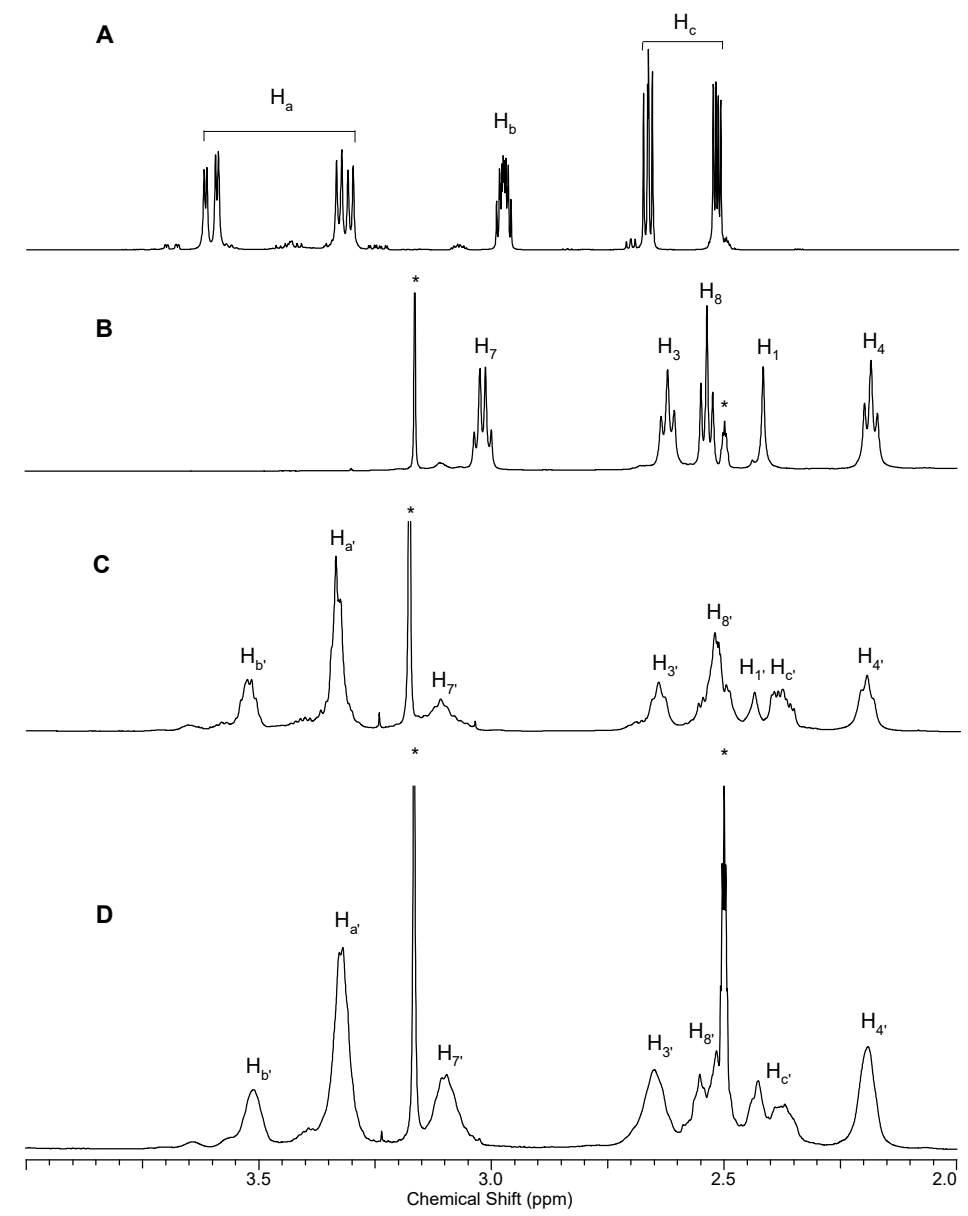

Figure 1. The relevant fragments of ${ }^{1} \mathrm{H}$ NMR spectra of: A-glycidol, B-PAMAM G0, C- $\mathbf{G}^{\mathbf{g l}}$, and $\mathbf{D}-\mathbf{G}^{\mathbf{g l}}{ }^{\mathrm{l}}$ in DMSO- $\mathrm{d}_{6}$. Resonances are labeled according to atom numbering in Scheme 1, Scheme 2, and Scheme 3. Residual $\mathrm{CD}_{3} \mathrm{SOCD}_{2} \mathrm{H}$ resonance and methanol are labeled with an asterisk. The ${ }^{1} \mathrm{H}$ resonances were assigned by COSY experiment. 


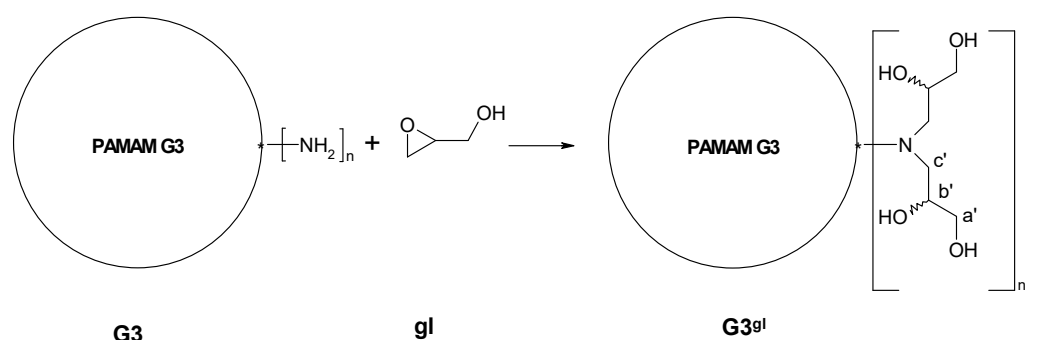

Scheme 2. Conversion of PAMAM G3 dendrimer to G3 $^{\text {gl }}$ by hydroxyalkylation with glycidol. PAMAM G3 has 32 terminal amine groups $(n=32)$ that each react with two molecules of gl to give a total of 64 2,3-dihydroxypropyl substituents with 128 free hydroxyl groups.<smiles>CS(=O)(=O)Nc1ccc([N+](=O)[O-])cc1Oc1ccccc1</smiles><smiles>CS(=O)(=O)N(C(=O)Oc1ccc([N+](=O)[O-])cc1)c1ccc([N+](=O)[O-])cc1Oc1ccccc1</smiles>

Scheme 3. Reaction pathway of nimesulide derivatization with $p$-nitrophenyl chloroformate (NPCF) with atom numbering of $\mathbf{1}$.

The same protocol was used to convert G3 into G3 ${ }^{\mathbf{g l}}$ (Scheme 2). The product was purified by extensive dialysis against water and characterized using ${ }^{1} \mathrm{H}$ NMR spectroscopy. The spectrum of G3 ${ }^{\mathbf{g}}{ }^{1}$ is shown in Figure 1, trace D. The spectrum of $\mathbf{G}^{\mathbf{g}^{\mathbf{l}}}$ is similar to that of $\mathbf{G}^{\mathbf{g l}}$ except for the intensities of resonances from the 2,3-dihydropropyl protons, which correspond to $[64 \mathrm{H}]$ for $b^{\prime}$ and $[128 \mathrm{H}]$ for $\mathrm{a}^{\prime}$ and $\mathrm{c}^{\prime}$ in comparison with PAMAM G3 $-\mathrm{CH}_{2}$-CO- resonance of intensity $[120 \mathrm{H}]$ at $2.2 \mathrm{ppm}\left(\mathrm{H}-4^{\prime}\right)$. The total intensity of carbon-attached ${ }^{1} \mathrm{H}$ resonances from G3 ${ }^{\mathrm{gl}}$ is $[804 \mathrm{H}]$, including $[484 \mathrm{H}]$ from the G3 core and $[320 \mathrm{H}]$ from peripheral glycidol-derived 2,3-dihydroxypropyl substituents.

The ${ }^{1} \mathrm{H}$ and ${ }^{13} \mathrm{C}$ NMR spectra of both $\mathbf{G} 0^{\text {gl }}$ and $\mathbf{G} 3^{\text {gl }}$ are quite complicated due to the racemic $\mathbf{g l}$ substrate used for synthesis. Therefore many stereoisomers are formed at every terminal di-substituted nitrogen, containing an attached chiral $\mathbf{g l}$ in combinations $R R, S S, R S$, and $S R$ local chirality. When considering only four microstates, two spectra of gl substituents can be expected-one from two meso forms and a second from chiral $R R$ and $S S$ microstates. Because more than two spectra are observed, it is obvious that two arms of the outer sphere of dendrimer influence the symmetry of NMR spectra. Namely, 16 microstates must be considered: RRRR; RRRS; ... RSSS ; SSSS, from which six various spectra of relative intensity, 1:1:1:1:2:2, should be observed if no enantiodiscrimination of chiral gl addition occurs. Still, the ${ }^{13} \mathrm{C}$ NMR spectra show at least four sets of resonances. Additionally, their intensities do not follow the 1:1:1:1:2:2 ratio indicating that a stereochemical discrimination factor for a second $\mathbf{g l}$ addition influences the populations of microstates. We are currently working on determination of $\mathbf{g l}$ addition enantioselectivity. Despite the structural complexity of $\mathbf{G} 3^{{ }^{\mathbf{l}}}$, the chemical availability of the terminal hydroxyl group of the 2,3-dihydroxypropyl substituents for further functionalization enables further expansion of the $\mathbf{G} 3^{\mathrm{gl}}$ dendrimer.

\subsubsection{Nimesulide Activation and Attachment to PAMAM G0}

$p$-Nitrophenyl chloroformate (NPCF) provides a one-carbon linker to amine groups of PAMAM dendrimers. It has been shown that the copolymer obtained from butylene oxide and ethylene oxide was efficiently activated with NPCF, followed by covalent attachment of PAMAM G1-G3 dendrimers [16]. 
Nimesulide was activated by obtaining the N-(4-nitrophenoxycarbonyl) derivative 1 from reaction of NPCF with N. Derivative 1 was fully characterized using NMR, mass spectrometry, and crystallography (Scheme 3). The schematic view of $\mathbf{1}$ is shown in Figure 2.

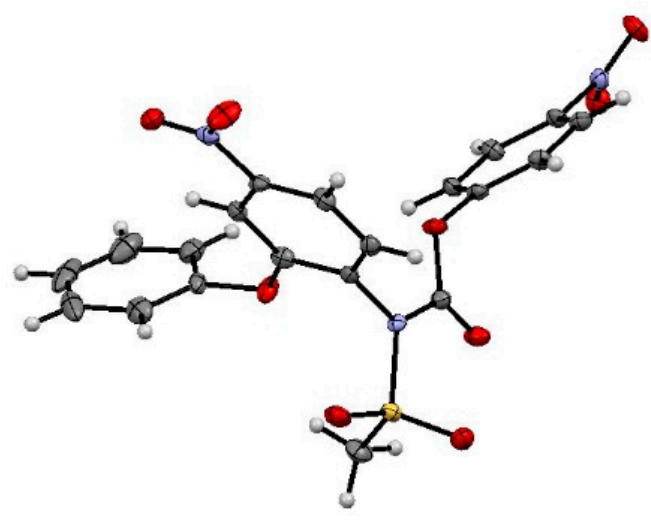

Figure 2. Schematic view of $\mathbf{1}$ ( $\mathrm{C}-$ gray, $\mathrm{N}-$ blue, $\mathrm{O}-$ red, $\mathrm{S}-$ yellow). The crucial bond lengths and angles are $\mathrm{S}-\mathrm{C}_{1}=1.75 ; \mathrm{S}-\mathrm{N}=1.69 ; \mathrm{N}_{1}-\mathrm{C}_{2}=1.45 ; \mathrm{N}_{1}-\mathrm{C}_{14}=1.38 \AA, \mathrm{C}_{2}-\mathrm{N}-\mathrm{S}=118.3(2)^{\circ}$, respectively (atom numbering according to Scheme 3 and deposited cif in $\mathrm{CCDC}$ ). All bond lengths and torsion angles are collected in Table A1 (Appendix A).

The X-ray structure of $\mathbf{N}$ was reported in 1995 [17]. Significant changes in bond lengths occur around the central sulfonamide nitrogen upon replacement of the hydrogen atom by 4-nitrophenylcarbonate in 1, namely elongation of the N-S bond from 1.64 to $1.69 \AA, N-C_{2}$ bond from 1.41 to $1.45 \AA$, and $\mathrm{S}-\mathrm{C}_{1}$ from 1.47 to $1.75 \AA$. The torsion angle $\mathrm{S}-\mathrm{N}-\mathrm{C}_{2}$ tightens from $124.7^{\circ}$ in $\mathrm{N}$ to $118.3^{\circ}$ in $\mathbf{1}$ due to steric hindrance of the 4-nitrophenylcarbonate substituent. We have noticed that $\mathbf{1}$ is stable in aqueous solution but reacts readily with amine groups on PAMAM G0.

Thus, 1 was used to covalently attach $\mathbf{N}$ via one-atom linker to PAMAM G0 to give G0 substituted with two molecules of $\mathbf{N}$ (Scheme 4). The urea bond formation was accompanied by release of 4-nitrophenol, which was removed by rinsing with chloroform. The characteristic IR carbamate $v(\mathrm{CO})$ band centered at $1755 \mathrm{~cm}^{-1}$ in $\mathbf{1}$ disappeared in $\mathbf{G 0}^{2 \mathrm{~N}}$ and was replaced by a $v(\mathrm{CO})$ band centered at $1644 \mathrm{~cm}^{-1}$ from $\mathbf{G} 0$ amide and a urea bond between $\mathbf{N}$ and $\mathbf{G 0}$ (Figure A1). Obtained $\mathbf{G} 0^{2 \mathbf{N}}$ was further used to attach it to core $\mathbf{G}^{\mathrm{gl}}$ after its activation with 14 equivalents of NPCF.
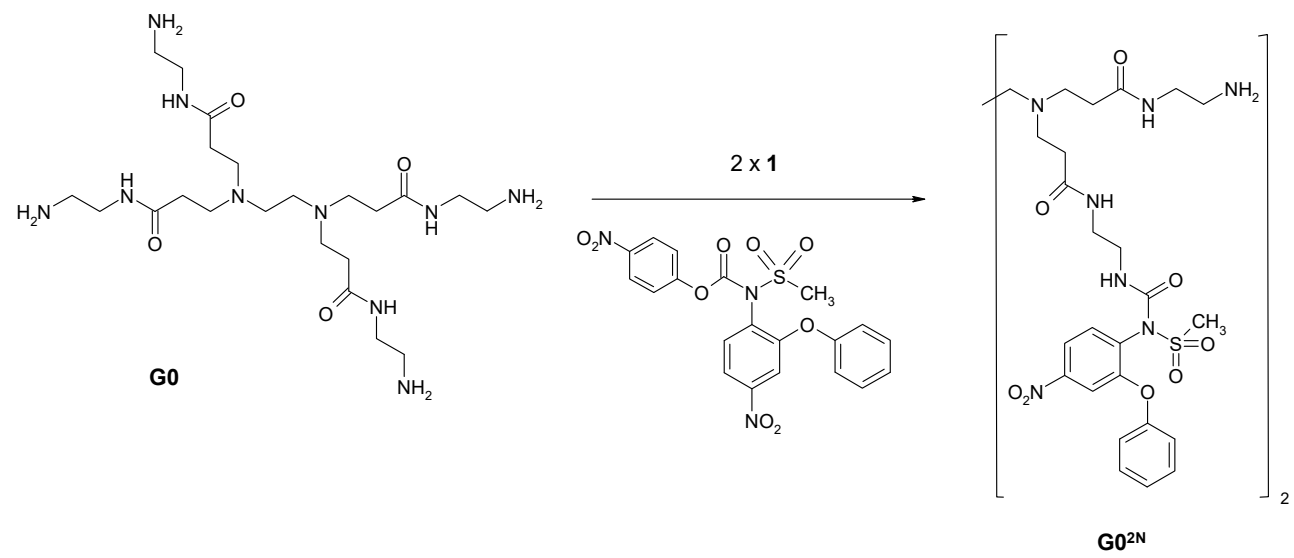

Scheme 4. Synthesis of PAMAM G0 double substituted with $\mathbf{N}$ via carbonyl linker $\left(\mathrm{G} 0^{2 \mathrm{~N}}\right)$.

\subsubsection{Synthesis of Megamer with Conjugated G0}

$\mathrm{G}^{\mathrm{gl}}$ was activated with 14 equivalents of NPCF in dry dimethylsulfoxide in the presence of excess TEA and used without isolation to bind 12 equivalents of $\mathbf{G} 0^{2 \mathbf{N}}$ (Scheme 5). 


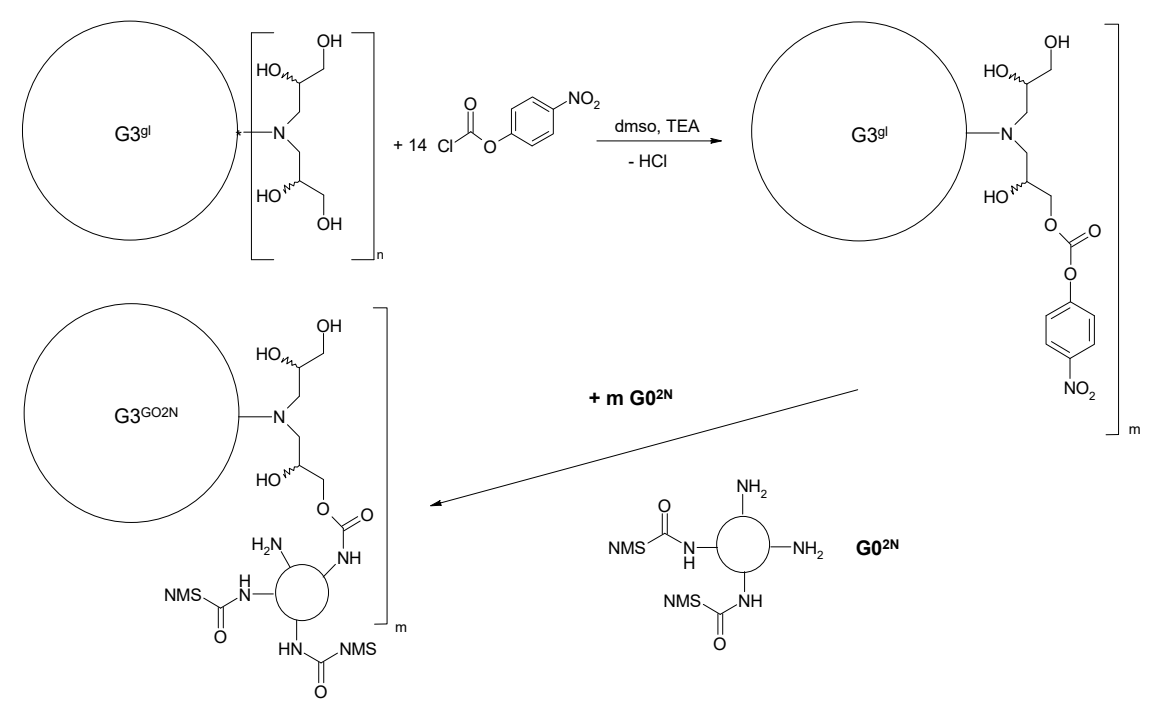

Scheme 5. Synthesis scheme of megamer composed of $\mathbf{G}^{\mathbf{g l}}$ core $(n=32)$, to which one-carbon linker is provided by reaction with $p$-nitrophenyl chloroformate (14 equivalents, $m=12$ ). Here, NMS represents nimesulide.

The mixture was dialyzed extensively against water. The stoichiometry of the obtained megameric conjugate was determined by the ${ }^{1} \mathrm{H}$ NMR spectrum of the product (Figure 3). Total integral intensity of $\underline{\mathrm{CH}}$ resonances of $\mathrm{G}^{\mathrm{gl}}$ corresponds to $[804 \mathrm{H}]$ while intensities of $\mathrm{OH}$ and $\underline{\mathrm{N}}$ signals are $[128 \mathrm{H}]$ and ca $[60 \mathrm{H}]$, respectively (trace A). In the ${ }^{1} \mathrm{H}$ NMR spectrum of $\mathrm{G}^{\mathrm{G}} \overline{\mathbf{0 2}} \mathbf{N}$, the nimesulide aromatic proton resonance intensity (in the 8-7 ppm region) corresponds to [192H] (24 $\mathbf{N}$ attached) versus broad $\mathrm{C} \underline{\mathrm{H}}$ signals intensity $[1308 \mathrm{H}]$ in the $4-2 \mathrm{ppm}$ region (trace B). The core $\mathrm{G}^{64 \mathrm{gl}}$ contribution is $[804 \mathrm{H}]$, while additional intensity derives from $12 \mathbf{G 0}([432 \mathrm{H}])$ and methyl groups of $\mathbf{N}([72 \mathrm{H}])$. The $\mathrm{OH}$ proton resonance is spread over the $4.25-5.25 \mathrm{ppm}$ region and therefore integration of it is unreliable, as are $\mathrm{NH}$ broad resonances centered at $7.84 \mathrm{ppm}$. Thus, the average megameric conjugate bears $24 \mathbf{N}$ prodrug units linked to $\mathbf{G} 0$ via urea bonds, while $\mathbf{G 0}^{2 \mathbf{N}}$ subunits are linked to the $\mathbf{G}^{\text {gl }}$ core by carbamate bonds. IR spectra of the $\mathbf{G}{ }^{\mathrm{gl}}$ core show a strong carbonyl stretching vibration band $v(\mathrm{CO})$ centered at $1634 \mathrm{~cm}^{-1}$, while $v(\mathrm{CO})$ for the urea bond (maximum at $1644 \mathrm{~cm}^{-1}$ ) in $\mathbf{G} 0^{2 \mathbf{N}}$ is overlapped with that of amide $v(C O)$ of $\mathbf{G 0}$. The $v(\mathrm{CO})$ of the carbamate bond between $\mathbf{G}^{\mathbf{g}}{ }^{\mathbf{l}}$ and $\mathbf{G} \mathbf{0}$ in megamers was observed at $1733 \mathrm{~cm}^{-1}$, well separated from other $v(\mathrm{CO})$ bands (Figure A1). 


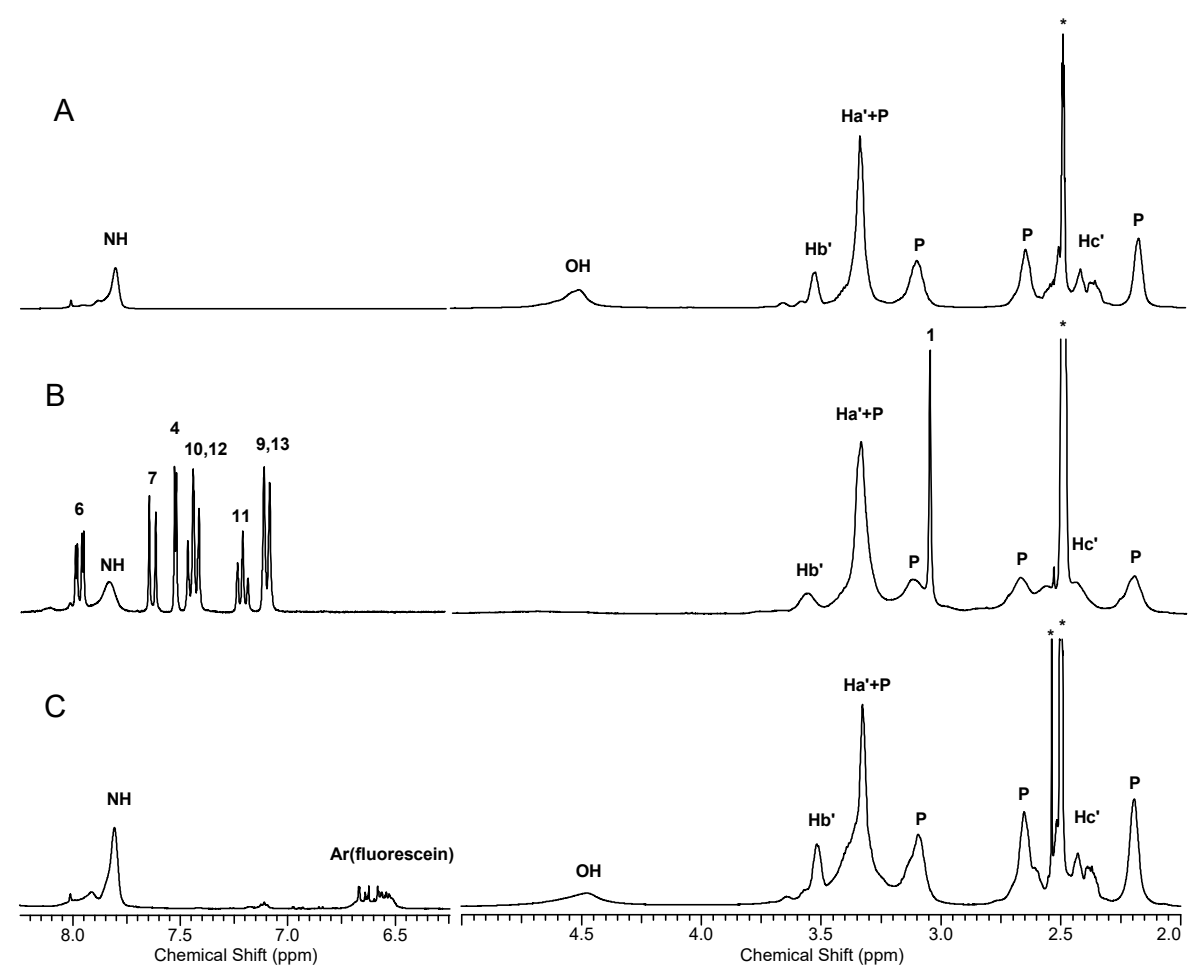

Figure 3. The relevant fragments of ${ }^{1} \mathrm{H} N M R$ spectra of: $\mathrm{A}-\mathrm{G} 3^{\mathrm{gl}}, \mathbf{B}-\mathrm{G}^{\mathrm{G}}{ }^{\mathrm{O} 2 \mathrm{~N}}, \mathrm{C}-\mathrm{G} 3^{\mathrm{G} 0 \mathrm{~F}}$ in DMSO- $\mathrm{d}_{6}$. Intensity of resonances in the left trace $\mathrm{B}$ was multiplied by factor of 2 . The resonances of nimesulide aromatic protons are labeled according to numbering shown in Scheme 3. The resonances from PAMAM G3 and PAMAM G0 cores are labeled P, while signals from 1,2-dihydroxypropyl substituents are labeled according to Scheme 2. Residual solvent and impurity resonances are labeled with asterisks.

A similar synthesis of megameric conjugate was performed for FITC-labeled G0 $\left(\mathrm{G}^{\mathrm{F}}\right)$. We deliberately used only four equivalents of NPCF to activate $G 0^{\mathrm{gl}}$ and 4 equivalents of $\mathrm{G}^{\mathrm{F}}$ to obtain $\mathrm{G}^{\mathrm{G}}{ }^{\mathrm{FF}}$ for preliminary confocal microscopy studies on cell cultures. The ${ }^{1} \mathrm{H}$ NMR spectrum of $\mathrm{G}^{\mathrm{GOF}}$ (trace $\mathrm{C}$ ) allowed us to determine the stoichiometry of this conjugate by integration of fluorescein aromatic resonances, which corresponds to [36H] $(9 \mathrm{H}$ per one FITC) versus [948H] from G3 ${ }^{\text {gl }}$ core $[804 \mathrm{H}]$ and 4 attached $\mathbf{G 0}[144 \mathrm{H}]$.

\subsubsection{Molecular Weight and Size of Dendrimers and Megamers}

The dispersity of molecular weight, molecular shape and size are important factors influencing the ability of the drug carrier to cross cell membranes by endocytosis. We determined the molecular weight of the obtained megamers, including the series of G2gl-G0, and G3gl-G0 synthesized in order to optimize the reagent stoichiometry in two-step synthesis followed by long purification of megamers by dialysis with water. The molecular weight and dispersity of megamers was determined using gel permeation chromatography (GPC) with dimethylformamide eluent. The column was calibrated with a series of G2-G5 dendrimers substituted with glycidol, for which we determined the average composition using ${ }^{1} \mathrm{H}$ NMR spectra. Thus the reference compounds were very similar chemically to the dendrimers tested.

We have found that $\mathbf{G}^{\text {gh }}$, upon reaction with 18 equivalents of NPCF followed by addition of 20 equivalents of $\mathbf{G} 0$ to give $\mathrm{G}_{3}{ }^{\mathrm{G} 0}$, showed $\mathrm{M}_{\mathrm{w}}$ corresponding to stoichiometry 1:13, while after prolonged dialysis of the same sample, the stoichiometry dropped to 1:10 (samples are named $\mathrm{G}^{\mathrm{G}}{ }^{\mathrm{C}} \mathrm{b}$ before and $\mathrm{G}^{\mathrm{G} 0} \mathrm{a}$ after dialysis, see Figure A2 and Table A2). Also using GPC, we found that G3:G0 stoichiometry in the $\mathbf{G} 3^{\mathbf{G} 02 \mathrm{~N}}$ megamer was 1:9, which corresponds to $18 \mathbf{N}$ equivalents per one megamer. This is very similar stoichiometry to that obtained from integration of resonances of $\mathbf{N}$ in ${ }^{1} \mathrm{H}$ NMR spectrum 
of $\mathrm{G}^{\mathrm{G} 02 \mathrm{~N}}$ megamer (vide supra). Thus the prolonged dialytic purification of megamers with water resulted in ca $10-25 \%$ loss of G0 from a megamer.

The molecular size of the megamers was estimated using the DLS method and compared to a series of $\mathrm{GM}^{\mathrm{gl}}$ dendrimers synthesized to serve as a reference series, in addition to known $\mathrm{GM}$ dendrimers (where $M$ is generation 2-5). The DLS-estimated diameters for dendrimers and megamer (determined in volume mode) are collected in Table A3. The G3 ${ }^{\mathbf{G} 02 \mathrm{~N}}$ megamer diameter was $5.07 \pm$ $0.14 \mathrm{~nm}$, which is similar to that of $\mathrm{G}^{\mathrm{gl}}(5.12 \mathrm{~nm})$.

\subsubsection{Structural and Height Analysis of Dendrimers Using AFM}

The height of dendrimers $\mathrm{G}^{\mathrm{gl}}{ }^{\mathrm{l}}, \mathrm{G} 3^{\mathrm{G} 0 \mathrm{~F}}$ and $\mathrm{G}^{\mathrm{G}}{ }^{\mathrm{G} 2 \mathrm{~N}}$ characterized using AFM is presented in Figure 4. In the case of $\mathbf{G}^{\mathrm{gl}}{ }^{\text {, }}$, two populations are observed with heights $1.8 \pm 0.9 \mathrm{~nm}$ and $3.5 \pm 0.6 \mathrm{~nm}$ $(n=66)$, respectively (Figure $4 \mathrm{~A})$. For $\mathrm{G}^{\mathrm{G}}{ }^{\mathrm{GF}}$, two populations are observed with heights $3.8 \pm 1.3 \mathrm{~nm}$ and $5.4 \pm 0.2 \mathrm{~nm}(n=28)$ (Figure $4 \mathrm{C})$. In the case of conjugate $\mathbf{G}_{3}{ }^{\mathbf{G} 02 \mathrm{~N}}$, populations with the heights $8.5 \pm 0.2 \mathrm{~nm}$ and $9.8 \pm 0.5 \mathrm{~nm}(n=16)$ (Figure 4E) were observed.

A linear relationship was found by plotting the measured height of dendrimers as a function of molecular weight with high correlation $\left(R^{2}=0.9993\right)$ (Figure $4 \mathrm{~F}$ ). To determine the distribution of acquired numerical data, histograms were plotted and a Jarque-Bera test was performed. None of data series describing vertical distance of dendrimers comes from a normal distribution ( $p$-value $<$ 0.05). The set of vertical distance data was also tested for the presence of outliers by means of a modified Thompson tau test. For all dendrimers, data outliers were found at the $95 \%$ confidence level. Occurrence of outliers may be evidence of gradual aggregation of dendrimers, which take the form of larger objects on the mica surface. 

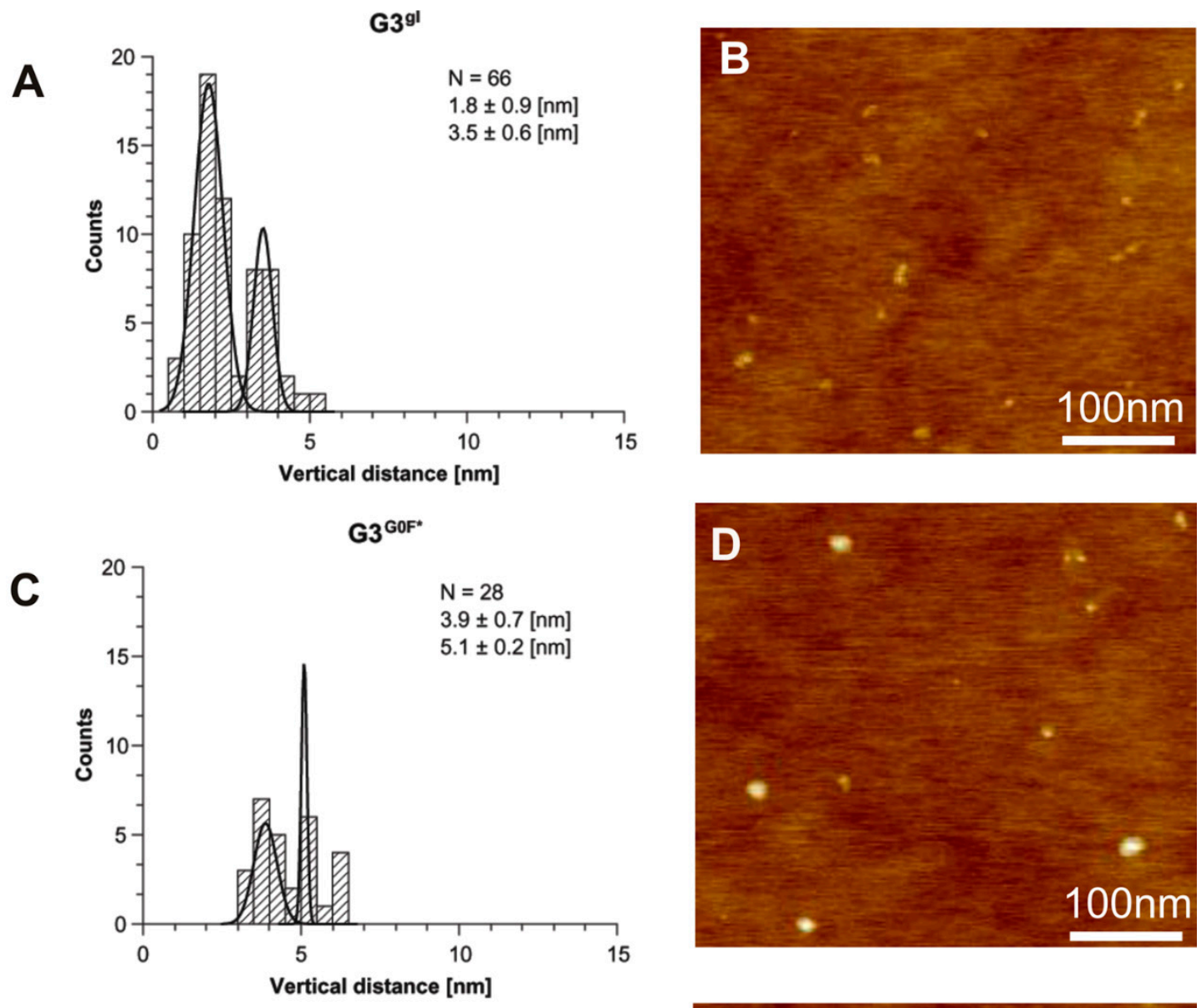

E
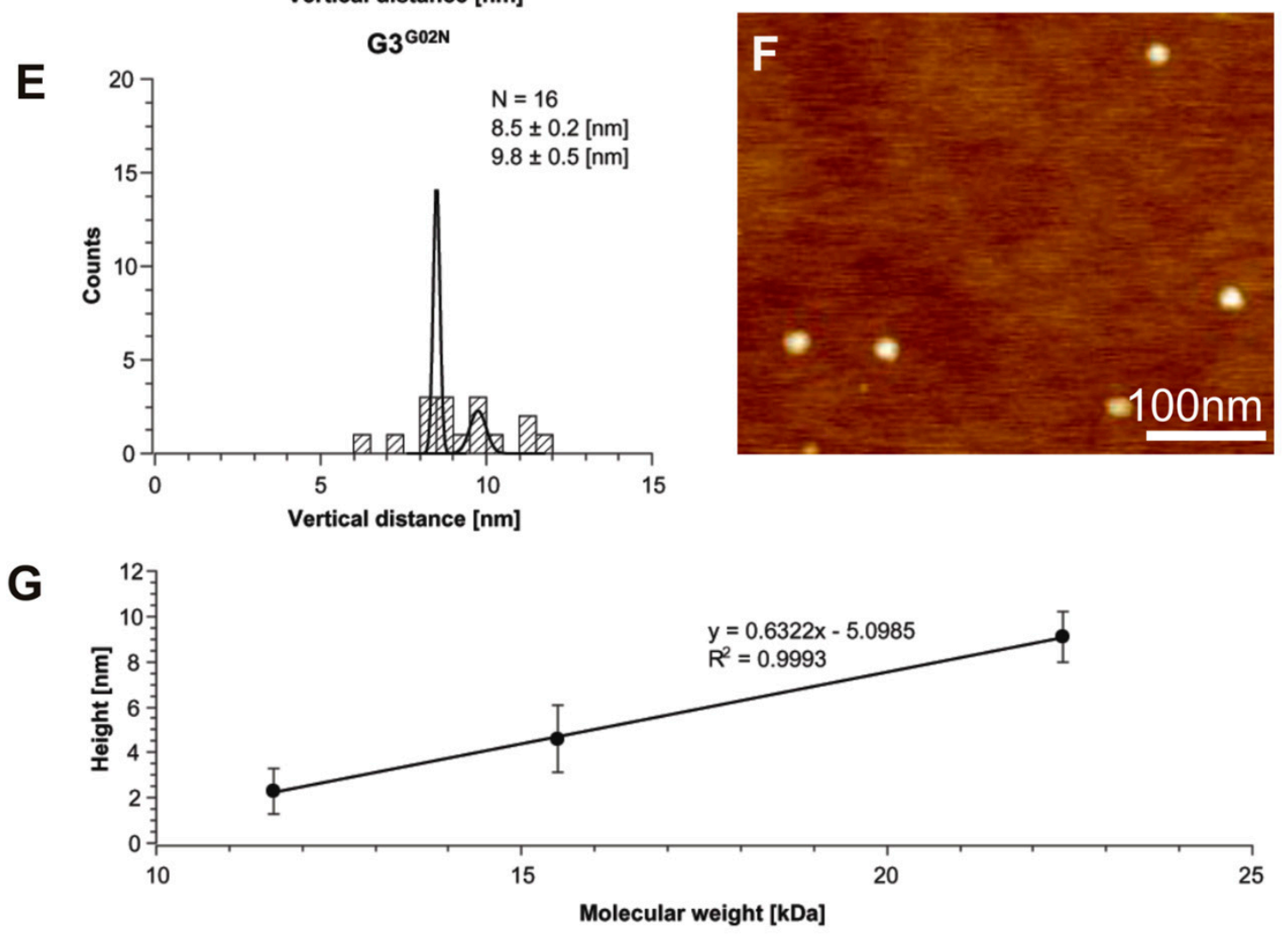

Figure 4. AFM images with height diagrams of dendrimers: $(\mathrm{A}, \mathrm{B}) \mathrm{G} 3^{\mathrm{gl}}$; (C,D) G3 ${ }^{\mathrm{G} 0 \mathrm{~F}} ;(\mathrm{E}, \mathrm{F}) \mathrm{G} 3^{\mathrm{G} 02 \mathrm{~N}}$; (G) Linear relationship of the dendrimer's height as a function of its molecular weight with high correlation coefficient $\left(R^{2}=0.9993\right)$. 


\subsection{Biology}

\subsubsection{Cytotoxicity}

To evaluate the utility of synthesized megameric conjugate $\mathrm{G}^{\mathrm{G}}{ }^{\mathrm{ON}}$ containing the cyclooxygenase-2 (COX-2) inhibitor nimesulide, three human cell lines were chosen: squamous carcinoma (SCC-15) and glioblastoma (U-118 MG), both overexpressing COX-2, and comparative normal human skin fibroblasts (BJ) with lower expression of COX-2 [3]. The cytotoxicity assay revealed inhibitory action of the studied conjugate at low $7.5 \mu \mathrm{M}$ concentration and, in the case of squamous carcinoma cells (SCC-15), even as low as $3.75 \mu \mathrm{M}$, after $24 \mathrm{~h}$ of exposure. At the highest concentration $(15 \mu \mathrm{M})$ all cell lines revealed about $50 \%$ decrease in viability. The most resistant were glioma cells and the least SCC-15 cells (Figure 5). Over the entire concentration range, the viability of squamous cell carcinomas was noticeably lower than other cell lines, particularly glioma cells. Statistical analysis revealed, however, that significant differences appeared at concentrations of 3.75 and $7.5 \mu \mathrm{M}$. Viability of normal fibroblasts had an intermediate degree. Microscope images collected during the assay performance confirmed obtained results. Changes in cell morphology were seen as concentration dependent cell shrinkage and decrease in cell number, cellular protrusion size and neutral red content in the lysosomes. The described symptoms of cell degradation were the most visible in SCC-15 cells. The biological effect of $\mathrm{G}_{3}{ }^{\mathrm{G} 02 \mathrm{~N}}$ appeared probably from the presence of $\mathbf{N}$ on the $\mathrm{G}^{\mathrm{G}}{ }^{\mathrm{G} 2 \mathrm{~N}}$ surface. As described in many papers, $\mathbf{N}$, a preferable COX-2 inhibitor, is a promising chemopreventive and antineoplastic agent that acts via blocking COX-2 and decreasing the concentration of prostaglandins inside the tumor or via other COX-independent pathways [18,19]. It was assumed that SCC-15 and U-118 MG cells with elevated COX-2 levels [3] would be more sensitive to a megamer containing N. SCC-15 cells showed a significant stronger decrease of viability at $3.75 \mu \mathrm{M}$ than normal cells with a lower COX-2 level. However, glioma cells did not react more strongly than BJ cells. Slightly more light is shed on this problem by our recent studies, where we showed that the action of nimesulide-substituted PAMAM G3 dendrimers selectively reduced the viability of SCC-15 cells compared to normal fibroblasts. However, this effect was not based on the COX-2 and $\mathrm{PGE}_{2}$ axis [4]. Therefore, it should be assumed that the action of the nimesulide substituted PAMAM dendrimers, including the tested megamer, can be also realized via independent $\mathrm{COX}-2$ and $\mathrm{PGE}_{2}$ pathways and requires further, profound studies of this issue. 

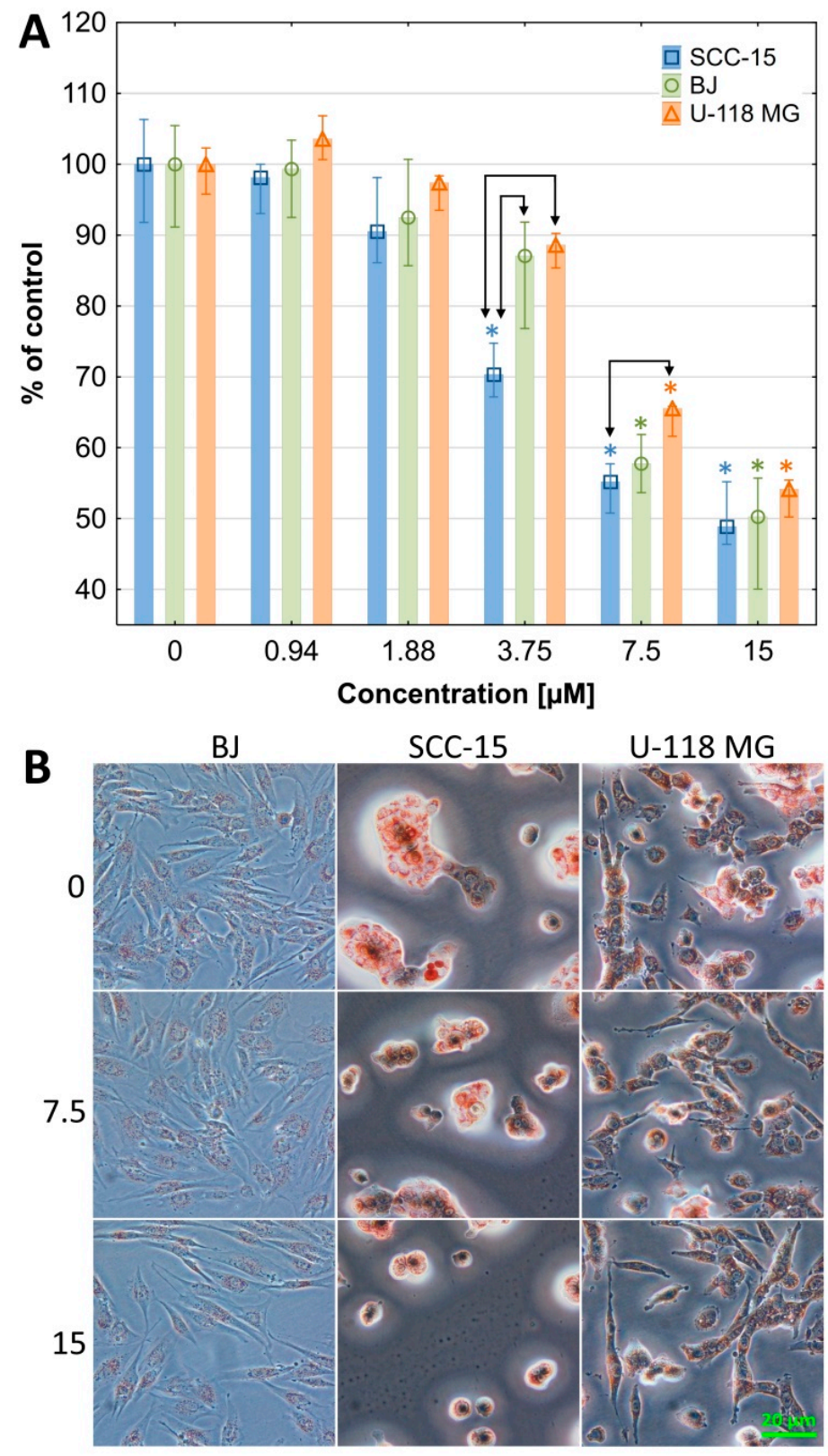

Figure 5. G3 ${ }^{\mathrm{G} 02 \mathrm{~N}}$ cytotoxicity against BJ, SCC-15 and U-118 MG cells after $24 \mathrm{~h}$ treatment. (A) Results are presented as median of triplicate assays from three independent experiments, expressed as a $\%$ of non-treated controls. The whiskers are the lower $(25 \%)$ and upper $(75 \%)$ quartile ranges. ${ }^{*} p<0.05$; Kruskal-Wallis test (against non-treated respective control). (B) Changes in cell morphology after $24 \mathrm{~h}$ treatment with $\mathrm{G} 3^{\mathrm{G} 02 \mathrm{~N}}$ and after $1 \mathrm{~h}$ incubation with neutral red. Red vesicles are lysosomes containing dye. Numbers indicate a micromolar concentration of $\mathbf{G} \mathbf{3}^{\mathbf{G} 0 \mathbf{N}}$. Images were obtained with a contrast phase microscope (Olympus IX-83).

Moreover, both PAMAM G0 and G3 dendrimers showed much lower toxicity to the cancer cells compared to obtained G3 ${ }^{\mathrm{G} 02 \mathrm{~N}}$. G0 PAMAM dendrimers were not toxic against colorectal adenocarcinoma (Caco-2) cells up to $10 \mathrm{mM}$ concentration after $3 \mathrm{~h}$ of incubation [20]. In addition, Zeng et al. demonstrated lack of G0 PAMAM dendrimer toxicity in human neural progenitor cells (hNPCs) up to $200 \mu \mathrm{M}$ concentration after 24 or even $72 \mathrm{~h}$ of incubation [21]. The PAMAM G3 $\mathrm{IC}_{50}$ for normal human fibroblasts (BJ) after $24 \mathrm{~h}$ incubation was higher than for SCC-15 cells $(7.5$ and $30 \mu \mathrm{M}$, respectively) [22]. Attachment of the PAMAM G0 dendrimer molecules with $\mathbf{N}$ to the G3 ${ }^{\mathbf{g l}}$ 
dendrimer resulted in a reversal of the biological effect on squamous carcinoma cells, which became more sensitive than normal human fibroblasts.

\subsubsection{Cellular Accumulation}

Fluorescent labeled megamer $\left(\mathrm{G}^{\mathrm{G}}{ }^{\mathrm{G} 2 \mathrm{~N}} *\right)$ penetrated into all three cell lines efficiently, but the profile of its cellular accumulation differed in particular cell types. The most efficient penetration of G3 ${ }^{\mathrm{G} 02 \mathrm{~N} *}$ was observed in SCC-15 cells at a concentration of $3.75 \mu \mathrm{M}$, similar to that in BJ and somewhat lower than in U-118 MG glioma cells (Figure 6A,B).
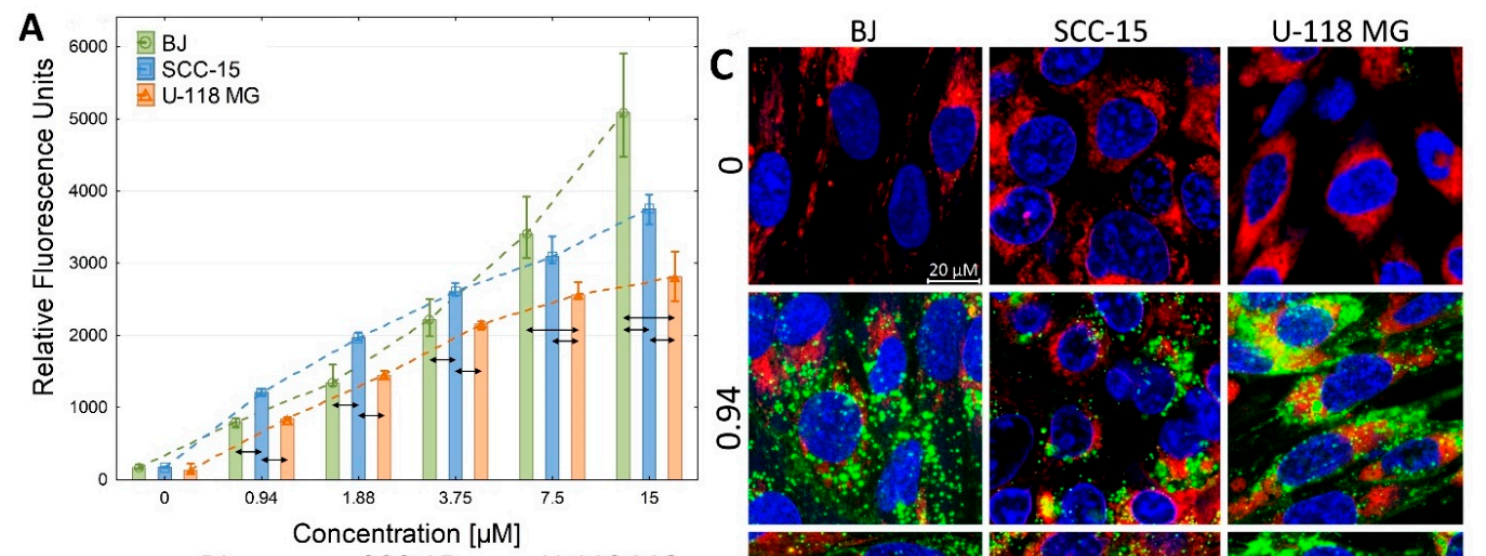

B


Figure 6. (A) Dose-dependent cellular accumulation of $\mathrm{G} 3^{\mathrm{G} 02 \mathrm{~N}} *$ in BJ, SCC-15 and U-118 MG cells after $24 \mathrm{~h}$ incubation. Results are presented as a median of triplicate assays from three independent experiments, expressed as a relative fluorescence unit per $2 \times 10^{4}$ cells. The whiskers are lower (25\%) and upper $(75 \%)$ quartile ranges. The arrows indicate differences in fluorescence between cell lines at appropriate concentrations, estimated with the Mann-Whitney $U$ test $(p<0.05)$. (B) Images present accumulation of $\mathrm{G}^{\mathrm{G} 02 \mathrm{~N}} *$ (green signal) after $24 \mathrm{~h}$ incubation obtained with a fluorescence microscope (Olympus IX-83). (C) Representative images from confocal microscopy showing degree of penetration of fluorescently labelled megamer (green signal) into DAPI labelled nuclei (blue signal) or MitoTracker labelled mitochondria (red signal). Micromolar concentrations of G3 ${ }^{\mathrm{G} 02 N}$ * are indicated.

At 7.5 and $15 \mu \mathrm{M}$ concentrations, the most efficient uptake was found in normal fibroblast cells, followed by SCC-15 and U-118 MG cells. The reason for this trend could be that BJ cells are more resistant to the toxic effects of $\mathrm{G}^{\mathrm{G}}{ }^{\mathrm{C} 2 \mathrm{~N}}$ and maintained a high degree of intracellular nanoparticle transport. Furthermore, phagocytic activity of these cells may be contributing to this phenomenon [23]. The lower accumulation of $\mathbf{G}^{\mathbf{G 0 2 N} *}$ in glioblastoma and SCC-15 cells may be caused by active xenobiotic efflux systems present in cancer cells, including gliomas [24].

The degree of fluorescently labelled megamer accumulation in mitochondria, nuclei or in other subcellular organelles after $24 \mathrm{~h}$ incubation were estimated with confocal microscopy by determining the degree of co-localization with fluorescently stained organelles. Studies revealed that $\mathrm{G}^{\mathrm{G}} \mathbf{G}^{\mathrm{N}} \mathrm{N}^{*}$ 
was present in intracellular compartments of all studied cell lines (Figure 6C). Most of the megamer absorbed by the cells remained in endocytic vesicles and in lysosomal vesicles. A significant part of the dendrimer was also dispersed in the cytoplasm of the cells, especially at higher concentrations of $\mathrm{G}^{\mathrm{G} 02 \mathrm{~N}^{*}}$. Only a small part accumulated in the mitochondria in a concentration dependent manner. In addition, $\mathrm{G}{ }^{\mathrm{G} 02 \mathrm{~N}^{*}}$ penetrated the mitochondria of normal fibroblasts and glioma cells to a larger degree than squamous carcinoma cells at all concentrations (Figure 6C, yellow signal). The penetration of the megamer into the nuclei was negligible and only noticeable in the case of normal fibroblast cells at the highest concentration of $15 \mu \mathrm{M}$ (Figure 6C, light blue signal). Our findings are in agreement with the observations of others concerning PAMAM dendrimers $[25,26]$. These results confirm that the studied megamer, in addition to its anticancer properties, can be a proper agent to deliver drugs into resistant cancer cells.

\subsubsection{Anti-Proliferation}

In this study, the megamer substituted with nimesulide $\mathrm{G}^{\mathrm{G}}{ }^{\mathrm{O} 2 \mathrm{~N}}$ was synthesized as a highly promising anti-cancer agent due to its anti-proliferative properties. $\mathbf{N}$ exert a strong anti-proliferative effect by promoting cell cycle arrest in multiple gastric cancer cell lines [27]. Moreover, the anti-proliferative action of this highly preferable COX-2 inhibitor was demonstrated against non-small cell lung cancer, hepatoma SMMC-7721 cells, human gastric adenocarcinoma SGC7901 cells, human pancreatic cancer cells and human esophageal adenocarcinoma OE33 cells [18,28].

In this study, $\mathrm{G}^{\mathrm{G} 02 \mathrm{~N}}$ revealed strongly selective, antiproliferative action against cancer cells compared to normal fibroblasts after $72 \mathrm{~h}$ incubation (Figure 7).



Figure 7. Influence of G3 ${ }^{\text {G02N }}$ on BJ, SCC-15 and U-118 MG cell proliferation after $72 \mathrm{~h}$ incubation, estimated after DAPI staining. Data are presented as \% of non-treated control. Results are a median of triplicates from three independent experiments. The whiskers are lower $(25 \%)$ and upper $(75 \%)$ quartile ranges. ${ }^{*}$ indicate statistically significant differences estimated with the Kruskal-Wallis test $(P<0.05)$.

The inhibition of cell division was particularly evident in the SCC-15 line and only slightly weaker in the case of glioblastoma cells, with $\mathrm{IC}_{50}$ values of 3.19 and $4.48 \mu \mathrm{M}$, respectively, compared to $9.28 \mu \mathrm{M}$ for normal human fibroblasts. Likewise, the strong inhibitory action of nimesulide after $72 \mathrm{~h}$ incubation against human squamous carcinoma cells (A431) was observed by Khodaie et al. with 
$\mathrm{IC}_{50}=250 \mu \mathrm{M}$ [29]. Differences in $\mathrm{IC}_{50}$ values for native drug and $\mathrm{G}^{\mathrm{G}}{ }^{\mathbf{0 2 N}}$ suggest that the decrease of cell proliferation is affected not only by nimesulide itself but also additionally by its megameric carrier. It has been noticed that proliferation of normal BJ cells grows to $134 \%$ at $1.88 \mu \mathrm{M}$ concentration. Similar cell growth enhancement was observed for PAMAM G2, G4, and G6 neat dendrimers in HeLa and HEK293T lines at 100-500 nM concentration of dendrimer [30].

\section{Materials and Methods}

\subsection{Materials}

PAMAM dendrimers were synthesized starting from ethylenediamine according to a modified protocol described by Tomalia [31]. All reagents for chemical syntheses, i.e., glycidol (mixture of enantiomers), methyl acrylate, ethylenediamine, and solvents, were purchased from Sigma-Aldrich (St Louis, Missouri, USA) as reagent grade and used as received. For biological studies, Eagle's Minimum Essential Medium (EMEM), Dulbecco's Modified Eagle's Medium (DMEM and DMEM: F-12), fetal bovine serum (FBS), penicillin and streptomycin solution were obtained from ATCC (Manassas, VA, USA). Trypsin-EDTA solution, phosphate-buffered saline (PBS) with and without magnesium and calcium ions, $0.4 \%$ trypan blue solution, fluorescent marker DAPI (4', 6 -diamidino-2-phenylindole, dihydrochloride) were purchased from Thermo Fischer Scientific (Waltham, Massachusetts, USA). Hydrocortisone, 0.33\% neutral red solution (3-amino-6-dimethylamino-2-methyl-phenazine hydrochloride), was obtained from Sigma-Aldrich (St Louis, Missouri, USA). Cell culture dishes were from Corning Incorporated (Corning, NY, USA) or Nunc (Roskilde, Denmark).

\subsection{Syntheses}

\subsubsection{Synthesis of PAMAM G0 Dendrimer Substituted with 8 Glycidol Molecules, G0g1}

Glycidol (gl, $0.9 \mathrm{~mL}, 0.967 \mathrm{~g}, 13.0 \mathrm{mmol}$ ) was added dropwise to a solution of PAMAM G0 (0.884 g, $1.63 \mathrm{mmol}$ ) in $20 \mathrm{~mL}$ of methanol with magnetic stirring. The mixture was left at room temperature for 2 days. Then methanol and excess $\mathbf{g l}$ were removed by vacuum rotary evaporation. Yellow syrup was obtained, which was identified using ${ }^{1} \mathrm{H}$ NMR as G0 $0^{\mathbf{}}$ (Figure 1).

${ }^{1} \mathrm{H}-\mathrm{NMR}$ (DMSO- $d_{6}$; for atom numbering see Scheme 1): chemical shift [ppm] (intensity, multiplicity, assignment): $7.83\left([4 \mathrm{H}], \mathrm{bs}, \mathrm{H}-6^{\prime}\right) ; 4.47([16 \mathrm{H}], \mathrm{bs}, \mathrm{OH}) ; 3.51 \mathrm{ppm}\left([8 \mathrm{H}], \mathrm{q}, \mathrm{H}_{\mathrm{b}^{\prime}}\right) ; 3.22 \mathrm{ppm}$ $\left([16 \mathrm{H}], \mathrm{m}, \mathrm{H}_{\mathrm{a}^{\prime}}\right) ; 3.09 \mathrm{ppm}\left([8 \mathrm{H}], \mathrm{H}-7^{\prime}\right) ; 2.63 \mathrm{ppm}\left([8 \mathrm{H}], \mathrm{t}, \mathrm{H}-2^{\prime}\right) ; 2.51 \mathrm{ppm}\left([8 \mathrm{H}], \mathrm{m}, \mathrm{H}-8^{\prime}\right) ; 2.42 \mathrm{ppm}$ $\left([4 \mathrm{H}], \mathrm{s}, \mathrm{H}-1^{\prime}\right) ; 2.33-2.40 \mathrm{ppm}\left([16 \mathrm{H}], \mathrm{m}, \mathrm{H}_{\mathrm{c}^{\prime}}\right) ; 2.18 \mathrm{ppm}\left([8 \mathrm{H}], \mathrm{t}, \mathrm{H}-4^{\prime}\right)$.

\subsubsection{Synthesis of PAMAM G3 Dendrimer Substituted with 64 Glycidol Molecules (G3 $\left.{ }^{\mathrm{gl}}\right)$ : The} Megamer Macromolecular Core

Dendrimer PAMAM G3 in methanol ( $525 \mathrm{mg}, 0.076 \mathrm{mmol}$ in $5 \mathrm{~mL} ; 15.2 \mathrm{mM}$ solution) was added dropwise into a $25 \mathrm{~mL}$ round bottom flask containing glycidol $(0.35 \mathrm{~mL}, 374 \mathrm{mg}, 5.10 \mathrm{mmol})$ in $2 \mathrm{~mL}$ of methanol. The mixture was left at room temperature for 2 days. After two days, the solution was transferred into a nitrocellulose dialytic bag $\left(\mathrm{MW}_{\text {cutoff }}=3 \mathrm{kDa}\right)$ and dialyzed against water for three days. Water was removed under reduced pressure by rotary evaporation and the resulting solid residue was dried under $0.2 \mathrm{~mm} \mathrm{Hg}$ pressure overnight. A $90 \%$ yield $(810 \mathrm{mg})$ of $\mathbf{G 3 g l}$ was obtained as a brown syrup and was characterized using ${ }^{1} \mathrm{H}$ NMR spectroscopy. The isolated G3 ${ }^{\text {gl }}$ macromolecular core was found to be very soluble in water and in dimethyl sulfoxide.

${ }^{1} \mathrm{H}-\mathrm{NMR}$ (DMSO- $d_{6}$; for atom numbering see Scheme 2): chemical shift [ppm] (intensity, multiplicity, assignment): $7.80([60 \mathrm{H}]$, bs $\mathrm{N} \underline{\mathrm{H}}) ; 4.47([128 \mathrm{H}], \mathrm{bs}, \mathrm{OH}) ; 3.51\left([64 \mathrm{H}], \mathrm{bs}, \mathrm{H}_{\mathrm{b}^{\prime}}\right) ; 3.33$ $\left([128 \mathrm{H}] \mathrm{H}_{\mathrm{a}^{\prime}}+[120 \mathrm{H}]\right.$ PAMAM); 3.10 ([120H], bs, PAMAM); 2.65 ([120H], bs, PAMAM); 2.30-2.45 $\left([128 \mathrm{H}], \mathrm{m}, \mathrm{H}_{\mathrm{c}^{\prime}}+[4 \mathrm{H}], \mathrm{s}\right.$, PAMAM); $2.20([120 \mathrm{H}]$, bs, PAMAM).

IR (Figure A1, Appendix A): $v(\mathrm{CO})=1634 \mathrm{~cm}^{-1}$. Theoretical molecular weight $=11645 \mathrm{Da}$. 
3.2.3. Synthesis of N-(4-Nitrophenoxycarbonyl) Nimesulid: N-(4-Nitrophenoxycarbonyl), $\mathrm{N}$-(4-Nitro-2-Phenoxyphenyl) Methanesulfonamide, 1

Nimesulide ( $220 \mathrm{mg}, 0.713 \mathrm{mmole})$ was dissolved in chloroform $(5 \mathrm{~mL})$ and triethylamine (TEA, $0.4 \mathrm{~mL})$. Then 4-nitrophenylchloroformate was added $(288 \mathrm{mg}, 1.43 \mathrm{mmoles})$ in portions with continuous stirring and the mixture was left under nitrogen at room temperature for $24 \mathrm{hrs}$. The chloroform layer was washed three times with water $(25 \mathrm{~mL})$ and the solvent was removed under reduced pressure. The mixture was chromatographed with chloroform: ethyl acetate (7:1) on silica gel. 1 was eluted as first fraction as identified using NMR and MS. Crystals of $\mathbf{1}$ were grown in an NMR tube upon layering the solution $(0.05 \mathrm{M})$ with hexane. The percent yield of 1 was $52.9 \%(250 \mathrm{mg})$.

Analytical data (for atom numbering see Scheme 3):

${ }^{1} \mathrm{H}$ NMR $\left(\mathrm{CDCl}_{3}\right): 8.25\left(\mathrm{~d}, \mathrm{~J}_{16-17}=9.2 \mathrm{~Hz},[2 \mathrm{H}], \mathrm{H}-17,19\right) ; 8.04\left(\mathrm{dd}, \mathrm{J}_{6-7}=8.7 \mathrm{~Hz}, \mathrm{~J}_{6-4}=2.5 \mathrm{~Hz}\right.$, [1H], H-6); $7.70(\mathrm{~d},[1 \mathrm{H}], \mathrm{H}-7) ; 7.69(\mathrm{~d}, 1 \mathrm{H}], \mathrm{H}-4) ; 7.46(\mathrm{t},[1 \mathrm{H}], \mathrm{H}-10,12) ; 7.32\left(\mathrm{t}, \mathrm{J}_{11-10}=7.3 \mathrm{~Hz},[1 \mathrm{H}]\right.$, H-11); 7.27 (d, [2H], H-16,20); 7.10 (d, J9-10 = 7.5 Hz, [2H], H-9,13); 3.54 (s, [3H], H-1).

${ }^{13} \mathrm{C}$ NMR $\left(\mathrm{CDCl}_{3}\right)$ : 154.7 (C-5); 154.2 (C-18 and C-8); 149.7 (C-14); 149.4 (C-3); 146.0 (C-15); 132.9 (C-6); 131.0 (C-10,12); 130.4 (C-2); 126.4 (C-11); 125.4 (C-17,19); 122.1 (C-16,20); 119.8 (C-9,13); 118.2 (C-7); 112.6 (C-4); 41.9 (C-1).

AuNPET LDI MS: $396.07\left(90 \%, \mathrm{Au}^{+}\right), 237.50\left(30 \%,[\mathbf{1}+2 \mathrm{H}]^{2+}\right) ; 393.93\left(100 \%, \mathrm{Au}_{2}{ }^{+}\right) ; 496.04[25 \%$, $1+\mathrm{Na}^{+} ; 590.90\left(60 \%, \mathrm{Au}_{3}{ }^{+}\right)$. Theoretical molecular mass for $\mathrm{C}_{20} \mathrm{~N}_{3} \mathrm{O}_{9} \mathrm{SH}_{15}-473.05$.

IR (in KBr): 1: $v(\mathrm{CO})=1756 \mathrm{~cm}^{-1} ; v_{\mathrm{as}}\left(\mathrm{NO}_{2}\right)=1526 \mathrm{~cm}^{-1} ; v_{\mathrm{as}}\left(\mathrm{SO}_{2}\right)=1301 \mathrm{~cm}^{-1}$, for comparison $\mathbf{N}: v_{\mathrm{as}}\left(\mathrm{NO}_{2}\right)=1522 \mathrm{~cm}^{-1} ; v_{\mathrm{as}}\left(\mathrm{SO}_{2}\right)=1293 \mathrm{~cm}^{-1}$.

\subsubsection{Synthesis of PAMAM G0-Bis-Carbonylnimesulide $\left(\mathrm{G}^{2 \mathrm{~N}}\right)$ and Single Fluorescein-Labeled} PAMAM G0 $\left(\mathrm{GO}^{\mathrm{F}}\right)$

$150 \mathrm{mg}(0.32 \mathrm{mmol})$ of 1 in chloroform $(1 \mathrm{~mL})$ was added to PAMAM G0 $(83 \mathrm{mg}, 0.16 \mathrm{mmol}$ in $4 \mathrm{~mL}$ methanol) at room temperature with vigorous stirring for $24 \mathrm{~h}$. Then the solution was heated to reflux for one hour and solvents were evaporated in vacuo. $\mathrm{G0}^{2 \mathrm{~N}}$ was rinsed with chloroform and isolated as pure compound in $35 \%$ yield.

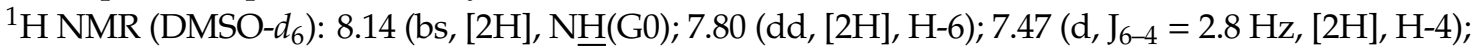
$7.31\left(\mathrm{~d}, \mathrm{~J}_{6-7}=9.4 \mathrm{~Hz},[2 \mathrm{H}], \mathrm{H}-7\right) ; 7.28(\mathrm{t},[4 \mathrm{H}], \mathrm{H}-10,12) ; 6.99\left(\mathrm{t}, \mathrm{J}_{10-11}=7.3 \mathrm{~Hz},[2 \mathrm{H}], \mathrm{H}-11\right) ; 6.84\left(\mathrm{~d}, \mathrm{~J}_{9-10}=\right.$

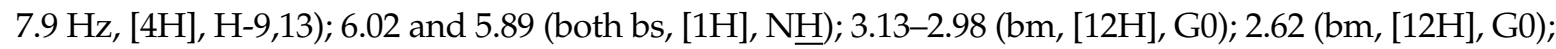
$2.58\left(\mathrm{~s},[6 \mathrm{H}], \mathrm{CH}_{3}-1\right) ; 2.41(\mathrm{~s},[4 \mathrm{H}], \mathrm{G} 0) ; 2.19$ (t, [8H], G0, $\left.\underline{\mathrm{C}}_{2}-\mathrm{CO}-\right)$. IR (Figure A1): $v(\mathrm{CO})=1644 \mathrm{~cm}^{-1}$.

Fluorescein labeled G0 was synthesized on a 0.10 mmolar scale. To the solution of $51.7 \mathrm{mg}$ (100 $\mu$ moles) PAMAM G0 in methanol $(2 \mathrm{~mL}$ ), fluorescein isothiocyanate (FITC, $38.9 \mathrm{mg}, 100 \mu$ moles in $2 \mathrm{~mL}$ methanol) was added stepwise with vigorous stirring. The red precipitate of $\mathbf{G 0}^{\mathrm{F}}$ was collected using filtration, washed with methanol and dried in vacuo.

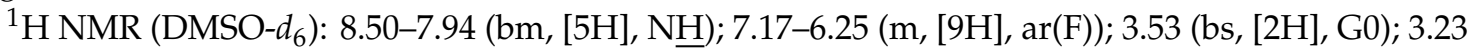
(bs, [2H], G0); 3.09 (bs, [6H], G0); 2.70-2.50 (overlapped m, [14H], G0); 2.34 (bs, [4H], G0); 2.24-2.00 (overlapped $\mathrm{m},[8 \mathrm{H}], \mathrm{G} 0$ ). IR (Figure A1): $v(\mathrm{CO})=1634 \mathrm{~cm}^{-1}$.

\subsubsection{Synthesis of megamers $\mathrm{G}^{\mathrm{gl}}-12 \mathrm{G} 0^{2 \mathrm{~N}}$ and $\mathrm{G} 3^{\mathrm{gl}}-4 \mathrm{G} 0^{\mathrm{F}}$}

G3 $^{\text {G02N }}$ : $100 \mathrm{mg} \mathrm{G}{ }^{\mathrm{gl}}$ (8.5 $\mu$ moles) was dissolved in $2 \mathrm{~mL}$ of DMSO and $0.5 \mathrm{~mL}$ of TEA. To this solution, solid NPCF (28.2 mg, $102 \mu$ moles) was added with vigorous stirring. The obtained mixture was immediately used to react with $119 \mathrm{mg}$ (100 $\mu$ moles) of $\mathbf{G} 0^{\mathbf{2 N}}$ in $2 \mathrm{~mL}$ DMSO at room temperature overnight. Then the mixture was dialyzed in nitrocellulose tubing $\left(\mathrm{MW}_{\text {cutoff }}=3 \mathrm{kDa}\right)$ against water for 4 days. Water was removed under reduced pressure and the ${ }^{1} \mathrm{H}$ NMR spectrum was recorded. Based upon integral intensity of $\mathbf{N}$ versus PAMAM resonances the stoichiometry of conjugate was determined to be $\mathbf{G}^{\mathbf{g l}}-\mathbf{1 2} \mathbf{G 0}^{\mathbf{2 N}}$ (see Figure 2).

${ }^{1} \mathrm{H}$ NMR (DMSO- $d_{6}$ ): N resonances: $7.98\left(\mathrm{dd}, \mathrm{J}_{6-7}=8.8 \mathrm{~Hz}, \mathrm{~J}_{6-4}=2.5 \mathrm{~Hz},[24 \mathrm{H}], \mathrm{H}-6\right) ; 7.63(\mathrm{~d}$, [24H], H-7); 7.52 (d, [24H], H-4); 7.44 (t, [48H], H-10,12); 7.21 (t, J11-10 = 6.4 Hz, [24H], H-11); 7.09 (d, $\left.\mathrm{J}_{9-10}=7.1 \mathrm{~Hz},[48 \mathrm{H}], \mathrm{H}-9,13\right) ; 3.05$ (s, [72H], H-1), PAMAM G3 ${ }^{\mathrm{gl}}+\mathrm{G0}$ resonances: 3.53 (bs, [64H], $\mathrm{H}_{\mathrm{b}^{\prime}}$ ); 
$3.33,3.12,2.97,2.85,2.67,2.57,2.45,2.21$ (unresolved broad resonances, ca [1200H], theor. [1172H] with contribution from $\mathrm{G} 3[484 \mathrm{H}], \mathrm{H}_{\mathrm{a}^{\prime}}$ and $\mathrm{H}_{\mathrm{c}^{\prime}}$ of $64 \mathrm{gl}[256 \mathrm{H}]$, and $\left.12 \mathrm{G} 0[432 \mathrm{H}]\right)$.

The weight-averaged molecular weight $\mathrm{M}_{\mathrm{W}}$ by GPC was ca $22.4 \mathrm{kDa}$ with $1.63 \mathrm{M}_{\mathrm{w}} / \mathrm{M}_{\mathrm{n}}$ dispersity (and $37 \mathrm{kDa}$ from $\mathrm{M}_{Z}$ ) vs theoretical average molecular weight 26,249 $\mathrm{kDa}$.

The $\mathrm{G}^{\mathrm{G}}{ }^{\mathbf{0 2 N}}$ conjugate was tested for toxicity against cancer cells. Additionally, ca $1 \mu \mathrm{mol}$ of $\mathrm{G}^{\mathrm{G}}{ }^{\mathrm{02N}}$ (26 mg) was labeled with one equivalent of FITC and used for confocal microscopic monitoring in cell lines $\left(\mathrm{G}^{\mathrm{G}}{ }^{\mathrm{G} 2 \mathrm{~N} *}\right.$, vide infra).

$\mathrm{G}^{\mathrm{GOF}}$ : $31 \mathrm{mg} \mathrm{G}^{\mathrm{gl}}$ (2.7 $\mu$ moles) was dissolved in $1.5 \mathrm{~mL}$ of DMSO and $0.3 \mathrm{~mL}$ of TEA. To this solution, solid NPCF ( $2.3 \mathrm{mg}$, $11.4 \mu$ moles) was added with vigorous stirring. Then, $0.115 \mathrm{~mL}$ of $0.10 \mathrm{M}$ $\mathrm{G0}^{\mathrm{F}}$ solution in DMSO (11.5 $\mu$ moles) was added and the mixture left for $24 \mathrm{~h}$ at room temperature. Then the mixture was dialyzed against water for 3 days in the dark. The solvents were removed under reduced pressure, yielding $35 \mathrm{mg}$ of $\mathbf{G}^{\mathbf{g l}}$. $\mathbf{G}^{\mathbf{g l}}$ was conjugated with 4 equivalents of $\mathbf{G} 0^{\mathrm{F}}$ based upon integral intensity of $\mathbf{F}$ aromatic resonances versus total intensity of $\mathbf{G} 3$ and $\mathbf{G} 0$ resonances. The estimated yield was $84 \%$. The average molecular weight determined using GPC was ca $15.5 \mathrm{kDa}$ vs theoretical molecular weight 15,383 for $\mathrm{G} 3-4 \mathrm{G} 0^{\mathrm{F}}$ stoichiometry. The aqueous solution of $\mathrm{G} 3{ }^{\mathrm{G} 0 \mathrm{~F}}$ was used to deposit the monomolecular layer in mica to estimate molecular size using AFM (vide infra).

${ }^{1} \mathrm{H}$ NMR (DMSO- $d_{6}$ ): $7.91+7.82$ (bs, bs, ca [70H], $\underline{\mathrm{H}}$ ); 6.71-6.50 (unresolved multiplets, [36H], aromatic $\underline{\mathrm{C}}$ from fluorescein); 4.47 (bs, ca $[110 \mathrm{H}], \mathrm{OH}$ ); PAMAM G3 ${ }^{\mathrm{gl}}+\mathrm{G0}$ resonances: 3.57-2.13 (total integrity ca $[950 \mathrm{H}]$ versus theoretical $[938 \mathrm{H}]$ with contribution from G3 ${ }^{\mathrm{gl}}[824 \mathrm{H}]$ and 4 G0 $[144 \mathrm{H}]$.

\subsection{Cell Cultures}

Human squamous cell carcinoma (SCC-15) and human glioblastoma (U-118 MG) cell lines obtained from ATCC (Manassas, VA, USA) were cultured in DMEM (doubling time 48 and $35 \mathrm{~h}$, respectively). Normal fibroblast (BJ) purchased from ATCC (doubling time 1.9 days) were grown in EMEM. Each medium was supplemented with 10\% heat-inactivated FBS and $100 \mathrm{U} / \mathrm{mL}$ penicillin, and $100 \mu \mathrm{g} / \mathrm{mL}$ streptomycin. Cells were cultured as described [22]. All biological tests were carried out in triplicates in three independent experiments.

\subsubsection{Cytotoxicity Neutral Red Assay (NR)}

BJ, SCC-15 and U-118 MG cells were seeded in flat-bottom 96-well culture plates in triplicates at a density of $1 \times 10^{4}$ cells/well. After $24 \mathrm{~h}$, working solutions of $\mathrm{G}^{\mathrm{G}}{ }^{\mathrm{G} 2 \mathrm{~N}}$ were prepared $(0.94-15 \mu \mathrm{M})$ in the corresponding culture media and added to cells (100 $\mu \mathrm{L} /$ well). The DMSO concentration was adjusted to $0.4 \%$ in all samples, which had no significant effect on treated cell lines. Following a $24 \mathrm{~h}$ incubation, an NR assay was performed as described before [32].

\subsubsection{Cellular Accumulation of Megamer}

Cells were seeded in 96-well plates at a density of $2 \times 10^{4}$ cells/well (BJ and U-118 MG) or $4 \times 10^{4}$ (SCC-15). After $24 \mathrm{~h}$ incubation cells were treated with $\mathrm{G} 3^{\mathrm{G} 02 \mathrm{~N} *}$ in the range of concentration $0-15 \mu \mathrm{M}$ in complete medium for $24 \mathrm{~h}$. After incubation plates were centrifuged ( $2000 \mathrm{rpm}, 5 \mathrm{~min})$, cells were washed with PBS and fixed with 3.7\% formaldehyde. Then, $600 \mathrm{nM}$ DAPI solution in PBS was added $(100 \mu \mathrm{L} /$ well $)$ and incubated for $1 \mathrm{~h}$ at room temperature. Fluorescence signals were read at $485 / 530 \mathrm{~nm}$ for FITC and 360/460 nm for DAPI with an Infinite M200 PRO Microplate Reader (TECAN Group Ltd., Switzerland). The DAPI staining was used to estimate the number of cells and calculate fluorescence signals per equal cell number.

\subsubsection{Confocal Microscopy}

Cells were cultured on microscope chamber slides (Nunc, Denmark) for $48 \mathrm{~h}$ at a density of 60 $\times 10^{4}$ or $1.2 \times 10^{5}$ cells (for BJ and U-118 MG or SCC- 15 cells, respectively) in $400 \mu \mathrm{L}$ of complete medium. FITC-labeled megamer was added at 0 to $15 \mu \mathrm{M}$ concentrations ( $400 \mu \mathrm{L} /$ well). After $24 \mathrm{~h}$ of incubation and washing (2xPBS), the cells were fixed with $3.7 \%$ formaldehyde for $15 \mathrm{~min}$ and 
stained with $600 \mathrm{nM}$ DAPI solution in PBS (1 h, RT). Images from each well were collected using a confocal microscope (Olympus FV10i, Tokyo, Japan) at 488/530 nm for FITC, 405/461 nm for DAPI, and $644 / 665 \mathrm{~nm}$ for MitoTracker. Images were collected in the Z-axis position at the largest nuclear cross section area. Pinhole was set for 1 AU (airy unit) and the obtained images had an optical section thickness of approximately $1.02 \mu \mathrm{m}$. Image processing was performed with the ImageJ software (Bethesda, MD, USA).

\subsubsection{Proliferation Assay}

For assay, cells were seeded into 96 -well microplates at a density of $5 \times 10^{3}$ cells/well and incubated for $24 \mathrm{~h}$ at $37^{\circ} \mathrm{C}$. After medium removal, G3 ${ }^{\mathrm{G} 02 \mathrm{~N}}$ solutions were prepared as described above in medium $(200 \mu \mathrm{L} /$ well). The plates were then incubated for $72 \mathrm{~h}$. Then, plates were centrifuged (2000 rpm, $5 \mathrm{~min}$ ). Cells were then washed with PBS and fixed in 3.7\% formaldehyde solution in PBS and stained with $600 \mathrm{nM}$ DAPI solution in PBS $(100 \mu \mathrm{L} /$ well, $1 \mathrm{~h})$. The fluorescent signal, proportional to the number of cells, was measured in a Tecan Infinite M200 PRO Multimode Microplate Reader (TECAN Group Ltd., Switzerland) at 360/460 nm. The results were expressed as \% of the control (DMSO treated cells).

\subsection{Methods}

\subsubsection{Spectroscopy}

1-D ${ }^{1} \mathrm{H},{ }^{13} \mathrm{C}$ NMR as well as 2-D ${ }^{1} \mathrm{H}_{-}{ }^{1} \mathrm{H}$ COSY and ${ }^{1} \mathrm{H}_{-}{ }^{13} \mathrm{C}$ HSQC and $\mathrm{HMBC}$ spectra were recorded with Bruker $300 \mathrm{MHz}$ instrument. Gold enhanced target laser desorption ionization mass spectra were recorded with a Bruker Autoflex Speed reflectron time-of-flight mass spectrometer equipped with a SmartBeam II laser (352 $\mathrm{nm}$ ) in 80-2080 $\mathrm{m} / \mathrm{z}$ range [33].

IR spectra were taken with ALPHA FT-IR Bruker instrument in $\mathrm{KBr}$ pellets and ATR mode.

\subsubsection{Atomic Force Microscopy Studies}

AFM images were recorded in air with a Nanoscope IIId scanning probe microscope with Extender Module (Bruker). Standard tapping mode AFM probes (NanoAndMore, Watsonville, California, USA) were used with a resonance frequency in the range of $200-400 \mathrm{kHz}$, with a typical spring constant of $42 \mathrm{~N} / \mathrm{m}$ and with a nominal apex radius of silicon tip curvature around $7 \mathrm{~nm}$. The samples with dendrimers were placed on freshly cleaved ultra-clean mica (Nano and More) and incubated at room temperature for $60 \mathrm{sec}$. The mica discs were then rinsed with purified 18.2 $\mathrm{M} \Omega$ deionized water and dried using gentle nitrogen gas flow. All samples were measured at room temperature in air. Structural analysis and height measurements of acquired images were performed with Nanoscope v.6.13 software (Watsonville, California, USA).

\subsubsection{Molecular Weight Estimation with Gel Permeation Chromatography}

The average molecular masses, $M n, M w$ and dispersity $M w / M n$ of the products were measured using gel permeation chromatography (GPC) using a RI detector (Shodex RI-71). The GPC instrument was equipped with TSKgel GMH $\mathrm{HR}_{\mathrm{H}} \mathrm{M}$ and TSKgel $\mathrm{GMH}_{\mathrm{HR}}$ Guard column packed with styrene divinylbenzene-type gel. The measurements were performed at a temperature of $22^{\circ} \mathrm{C}$. All samples were dissolved in $\mathrm{N}, \mathrm{N}$-dimethylformamide (HPLC grade) containing $5 \mathrm{mmol} / \mathrm{L} \mathrm{LiCl}$. The flow rate of the carrier solvent was $1.00 \mathrm{~mL} / \mathrm{min}$. The sample injection volume was $100 \mu \mathrm{L}$. The average molecular masses and dispersity were determined using OmniSEC software (Dublin, Ireland). The G2, G3, and G4 PAMAM dendrimers bearing 46, 78, and 140 2,3-dihydroxyproyl substituents and averaged molecular weight: $6600,12,681$, and $24,575 \mathrm{Da}$, respectively for $\mathrm{G} 2^{46 \mathrm{gl}}, \mathrm{G} 3^{78 \mathrm{gl}}$, and G4 ${ }^{140 \mathrm{gl}}$ were used for calibration. For details see Appendix A: Figure A2 and Table A2. 


\subsubsection{Dynamic Light Scattering Measurements}

DLS measurements were performed using a Zetasizer nano ZS instrument. Measurements were made under back-scattering conditions (fixed scattering angle $173^{\circ}$ ). All dendrimers were dissolved in water at ca $1.0 \mathrm{mM}$ concentration. The size of dendrimers and megamers were calculated in volume mode. The results are presented graphically (Figure A3) and values of diameter [nm] are collected in Table A3.

\subsubsection{Crystallographic Measurements}

X-ray diffraction data of $\mathbf{1}$ was collected on an Xcalibur diffractometer with Saphire detector (Mo-K $\alpha$ radiation; $\lambda=0.71073 \AA$ ) at $100 \mathrm{~K}$. Data reduction and analysis were carried out with the CrysAlis program [34]. Structure was solved by direct methods using the SHELXS program and refined using all $F^{2}$ data, as implemented by the SHELXL program [35]. Non-hydrogen atoms were refined with anisotropic displacement parameters. All $\mathrm{H}$ atoms were placed at calculated positions, and before the last cycle of refinement all $\mathrm{H}$ atoms were fixed and were allowed to ride on their parent atoms.

$2\left(\mathrm{C}_{20} \mathrm{H}_{15} \mathrm{~N}_{3} \mathrm{O}_{9} \mathrm{~S}\right), \mathrm{CHCl}_{3}$, triclinic, $P-1, \mathrm{a}=10.583(3) \AA, \mathrm{b}=12.774(3) \AA, \mathrm{c}=17.974(3) \AA, \alpha=$ $72.60(3)^{\circ}, \beta=75.67(2)^{\circ}, \gamma=87.64(2)^{\circ}, \mathrm{V}=2245.1(10) \AA^{3}, \mathrm{~T}=100(2) \mathrm{K}, \mathrm{R}=0.062, \mathrm{wR}=0.123[5197$ reflections with $\mathrm{I}>2 \sigma(\mathrm{I})]$ for 631 variables.

The .cif file has been deposited in CCDC, number 1910753, and is available upon request via www.ccdc.cam.ac.uk.data/data_request.cif.

\section{Conclusions}

PAMAM G3 and G0 megamer composed of PAMAM G3 dendrimer with 64 terminal propyldiol substituents serving as a core and 12 PAMAM G0 subunits bearing carbonyl-linked nimesulide were obtained using $p$-nitrophenyl chloroformate as an efficient activator of both the hydroxyl group of the G3 core and nimesulide. The obtained conjugate is well soluble in water.

The G3 core is capable of binding ca 10 equivalents of $\mathrm{G} 0$ dendrimers to obtain a mixed generation megamer of molecular size within the range of other dendrimers, namely G3 $(3.6 \mathrm{~nm})<\mathrm{G}^{\mathrm{gl}}(3.9 \mathrm{~nm})$ $<\mathrm{G} 4(4.5 \mathrm{~nm}) \mathrm{G}^{\mathrm{G} 02 \mathrm{~N}}(5.1 \mathrm{~nm}) \leq \mathrm{G}^{\mathrm{gl}}(5.1 \mathrm{~nm})<\mathrm{G} 5(5.4 \mathrm{~nm})<\mathrm{G}^{\mathrm{gl}}(6.3 \mathrm{~nm})$. The molecular size of such dendrimer renders them good candidates for crossing the cell membrane via endocytosis, and PAMAM dendrimer generation 3-5 are used mostly as drug carriers.

The megamer-nimesulide conjugate with $\mathrm{G}^{\mathrm{gl}}$ core and $c a 12 \mathbf{G} 0^{\mathbf{2 N}}$ satellite dendrimers obtained was shown to effectively penetrate cells in micromolar concentrations. The conjugate has selective anticancer activity against human squamous carcinoma and glioma cells compared to normal human fibroblasts via inhibition of cell proliferation. Therefore, this megameric carrier provides a promising route for selective squamous carcinoma therapy. Additionally, megamers can be equipped with various drug and targeting molecules like biotin or folate, and other anticancer drugs that may additionally increase the effectiveness of anticancer therapy.

Author Contributions: Conceptualization, S.W., M.K. and Ł.U.; methodology, S.W. and Ł.U.; formal analysis, Ł.U.; investigation, M.Z., S.W., Ł.U, M.W., M.K., A.B., and P.S.; writing-original draft preparation, S.W., M.K., and Ł.U.; writing-review and editing, S.W. and D.A.; supervision, S.W. and M.K.; funding acquisition, Ł.U.

Funding: Biological studies were performed by ŁU and funded from NCN Grant 2014/13/D/NZ3/02825 (Poland). Conflicts of Interest: The authors declare no conflicts of interest.

\section{Appendix A}

Table A1. Bond lengths and torsion angles in $\mathbf{1}$.

\begin{tabular}{ll}
\hline Bond Lengths [A] & Torsion Angles $\left[^{\circ}\right]^{\circ}$ \\
\hline S1A O2A 1.424(2) & O2A S1A O1A 120.34(14) \\
S1A O1A 1.428(2) & O2A S1A N1A 103.73(14) \\
\hline
\end{tabular}


Table A1. Cont.

\begin{tabular}{|c|c|}
\hline Bond Lengths [Å] & Torsion Angles $\left[{ }^{\circ}\right]$ \\
\hline S1A N1A 1.691(3) & O1A S1A N1A 108.47(14) \\
\hline S1A C1A 1.757(3) & O2A S1A C1A 109.51(16) \\
\hline N1A C14A 1.379(4) & O1A S1A C1A 108.95(16) \\
\hline N1A C2A $1.456(4)$ & N1A S1A C1A 104.64(15) \\
\hline C2A C7A 1.364(4) & C14A N1A C2A 121.7(3) \\
\hline C2A C3A $1.399(4)$ & C14A N1A S1A 119.7(2) \\
\hline O3A C3A 1.373(4) & C2A N1A S1A 118.3(2) \\
\hline O3A C8A 1.411(4) & C7A C2A C 3 A $121.0(3)$ \\
\hline C3A C4A 1.377(4) & C7A C2A N1A 120.8(3) \\
\hline O4A N5A 1.238(3) & C3A C2A N1A 118.2(3) \\
\hline C4A C5A 1.377(4) & C3A O3A C8A 118.5(2) \\
\hline O5A N5A 1.218(3) & O3A C3A C4A 124.3(3) \\
\hline N5A C5A 1.483(4) & O3A C3A C2A 116.1(3) \\
\hline C5A C6A 1.381(4) & C4A C3A C2A 119.6(3) \\
\hline O6A C14A 1.359(4) & C5A C4A C3A 118.1(3) \\
\hline O6A C15A 1.410(4) & O5A N5A O4A 124.1(3) \\
\hline C6A C7A 1.392(4) & O5A N5A C5A 118.3(3) \\
\hline O7A C14A 1.194(4) & O4A N5A C5A 117.6(3) \\
\hline C8A C9A 1.365(5) & C4A C5A C6A 123.6(3) \\
\hline C8A C13A 1.384(5) & C4A C5A N5A 116.8(3) \\
\hline C9A C10A 1.391(5) & C6A C5A N5A 119.5(3) \\
\hline C10A C11A 1.389(6) & C14A O6A C15A 117.2(2) \\
\hline C11A C12A 1.372(6) & C5A C6A C7A 117.2(3) \\
\hline C12A C13A 1.369(5) & C2A C7A C6A 120.5(3) \\
\hline C15A C16A 1.373(4) & C9A C8A C13A 122.0(3) \\
\hline C15A C20A 1.382(4) & C9A C8A O3A 121.5(3) \\
\hline C16A C17A 1.397(4) & C13A C8A O3A 116.4(3) \\
\hline C17A C18A 1.377(4) & C8A C9A C10A 119.0(4) \\
\hline O18A N18A 1.233(3) & C11A C10A C9A 119.4(4) \\
\hline N18A O19A 1.229(3) & C12A C11A C10A 120.3(4) \\
\hline N18A C18A 1.459(4) & C13A C12A C11A 120.7(4) \\
\hline C18A C19A 1.395(4) & C12A C13A C8A 118.6(4) \\
\hline C19A C20A 1.390(4) & O7A C14A O6A 125.6(3) \\
\hline $\mathrm{S} 1 \mathrm{O} 21.424(2)$ & O7A C14A N1A 126.0(3) \\
\hline S1 O1 1.427(2) & O6A C14A N1A 108.4(3) \\
\hline S1 N1 1.687(3) & C16A C15A C20A 123.1(3) \\
\hline S1 C1 1.748(4) & C16A C15A O6A 118.0(3) \\
\hline N1 C14 1.393(4) & C20A C15A O6A 118.7(3) \\
\hline N1 C2 1.448(4) & C15A C16A C17A 118.7(3) \\
\hline C2 C7 1.378(4) & C18A C17A C16A 118.1(3) \\
\hline C2 C3 1.394(4) & O19A N18A O18A 123.7(3) \\
\hline O3 C3 1.368(4) & O19A N18A C18A 118.3(3) \\
\hline O3 C8 1.412(4) & O18A N18A C18A 118.0(3) \\
\hline C3 C4 1.384(4) & C17A C18A C19A 123.6(3) \\
\hline C4 C5 1.380(5) & C17A C18A N18A 118.6(3) \\
\hline O4 N5 1.231(4) & C19A C18A N18A 117.8(3) \\
\hline O5 N5 1.224(3) & C20A C19A C18A 117.5(3) \\
\hline N5 C5 1.480(4) & C15A C20A C19A 119.0(3) \\
\hline C5 C6 1.385(4) & O2 S1 O1 119.91(14) \\
\hline O6 C14 1.364(4) & O2 S1 N1 103.87(14) \\
\hline O6 C15 1.409(4) & O1 S1 N1 108.49(13) \\
\hline C6 C7 1.391(4) & O2 S1 C1 109.37(17) \\
\hline O7 C14 1.189(4) & O1 S1 C1 108.88(16) \\
\hline C8 C9 1.375(5) & N1 S1 C1 105.29(15) \\
\hline C8 C13 1.380(5) & C14 N1 C2 122.4(3) \\
\hline C9 C10 1.381(5) & C14 N1 S1 117.9(2) \\
\hline C10 C11 1.379(5) & C2 N1 S1 118.8(2) \\
\hline
\end{tabular}


Table A1. Cont.

\begin{tabular}{|c|c|}
\hline Bond Lengths [Å] & Torsion Angles [ $\left.{ }^{\circ}\right]$ \\
\hline C11 C12 1.369(5) & C7 C2 C3 121.0(3) \\
\hline C12 C13 1.375(5) & C7 C2 N1 120.3(3) \\
\hline C15 C20 1.369(4) & C3 C2 N1 118.6(3) \\
\hline C15 C16 1.387(4) & C3 O3 C8 117.8(2) \\
\hline C16 C17 1.388(5) & O3 C3 C4 123.9(3) \\
\hline C17 C18 1.385(4) & O3 C3 C2 116.0(3) \\
\hline O18 N18 1.228(4) & C4 C3 C2 120.1(3) \\
\hline N18 O19 1.233(3) & C5 C4 C3 117.3(3) \\
\hline N18 C18 1.468(4) & O5 N5 O4 123.8(3) \\
\hline C18 C19 1.381(4) & O5 N5 C5 118.5(3) \\
\hline C19 C20 1.384(5) & O4 N5 C5 117.8(3) \\
\hline Cl1 C100 1.737(4) & C4 C5 C6 124.2(3) \\
\hline Cl2 C100 1.765(4) & C4 C5 N5 116.6(3) \\
\hline \multirow{31}{*}{ Cl3 C100 1.754(4) } & C6 C5 N5 119.1(3) \\
\hline & C14 O6 C15 115.5(2) \\
\hline & C5 C6 C7 117.2(3) \\
\hline & C2 C7 C6 120.1(3) \\
\hline & C9 C8 C13 121.8(3) \\
\hline & C9 C8 O3 121.0(3) \\
\hline & C13 C8 O3 117.2(3) \\
\hline & C8 C9 C10 118.6(3) \\
\hline & C11 C10 C9 120.2(4) \\
\hline & C12 C11 C10 120.1(3) \\
\hline & C11 C12 C13 120.8(3) \\
\hline & C12 C13 C8 118.5(3) \\
\hline & O7 C14 O6 126.0(3) \\
\hline & O7 C14 N1 125.6(3) \\
\hline & O6 C14 N1 108.4(3) \\
\hline & C20 C15 C16 122.7(3) \\
\hline & C20 C15 O6 119.5(3) \\
\hline & C16 C15 O6 117.8(3) \\
\hline & C15 C16 C17 118.5(3) \\
\hline & C18 C17 C16 118.1(3) \\
\hline & O18 N18 O19 123.8(3) \\
\hline & O18 N18 C18 118.4(3) \\
\hline & O19 N18 C18 117.8(3) \\
\hline & C19 C18 C17 123.2(3) \\
\hline & C19 C18 N18 119.0(3) \\
\hline & C17 C18 N18 117.7(3) \\
\hline & C18 C19 C20 117.9(3) \\
\hline & C15 C20 C19 119.4(3) \\
\hline & Cl1 C100 Cl3 111.1(2) \\
\hline & Cl1 C100 Cl2 110.9(2) \\
\hline & $\mathrm{Cl} 3$ C100 Cl2 110.6(2) \\
\hline
\end{tabular}






Figure A1. Infrared spectra (from top to bottom) $\mathbf{N}$ (red); 1 (brown) (both in $\mathrm{KBr}$ pellet); G0 ${ }^{\mathbf{2 N}}$ (green), G3 ${ }^{\mathrm{G} 0}$ (blue), G3 ${ }^{\mathrm{gl}}$ (black); (all ATR).

Table A2. Molecular weight parameters determined using GPC (see Figure A2 for description).

\begin{tabular}{cccccc}
\hline Species & $\mathbf{M}_{\mathbf{n}}$ & $\mathbf{M}_{\mathbf{w}}$ & $\mathbf{M}_{\mathbf{z}}$ & $\mathbf{M}_{\mathbf{p}}$ & $\mathbf{M}_{\mathbf{w}} / \mathbf{M}_{\mathbf{n}}$ \\
\hline $\mathbf{G 3}^{\mathbf{G} 0} \mathbf{b}$ & 11860 & 18980 & 30930 & 14370 & 1.60 \\
$\mathbf{G 3}^{\mathbf{G 0}} \mathbf{a}$ & 11010 & 15050 & 20220 & 14920 & 1.37 \\
$\mathbf{G 3}^{\mathbf{G 0 2 N}}$ & 13740 & 22400 & 37230 & 17310 & 1.63 \\
\hline
\end{tabular}

Table A3. Molecular size of $\mathrm{GM}^{\mathrm{gl}}$ and $\mathrm{G} 3^{\mathrm{G} 02 \mathrm{~N}}$ measured using DLS method.

\begin{tabular}{|c|c|}
\hline Species & Diameter [nm] \\
\hline $\mathrm{G} 2^{\mathrm{gl}}$ & $3.24 \pm 0.11$ \\
\hline $\mathrm{G}^{\mathrm{gl}}$ & $3.94 \pm 0.11$ \\
\hline $\mathrm{G} 4^{\mathrm{gl}}$ & $5.12 \pm 0.12$ \\
\hline $\mathrm{G}^{\mathrm{gl}}$ & $6.35 \pm 0.14$ \\
\hline $\mathrm{G} 3 \mathrm{G} 0 \mathrm{~N}$ & $5.07 \pm 0.16$ \\
\hline
\end{tabular}




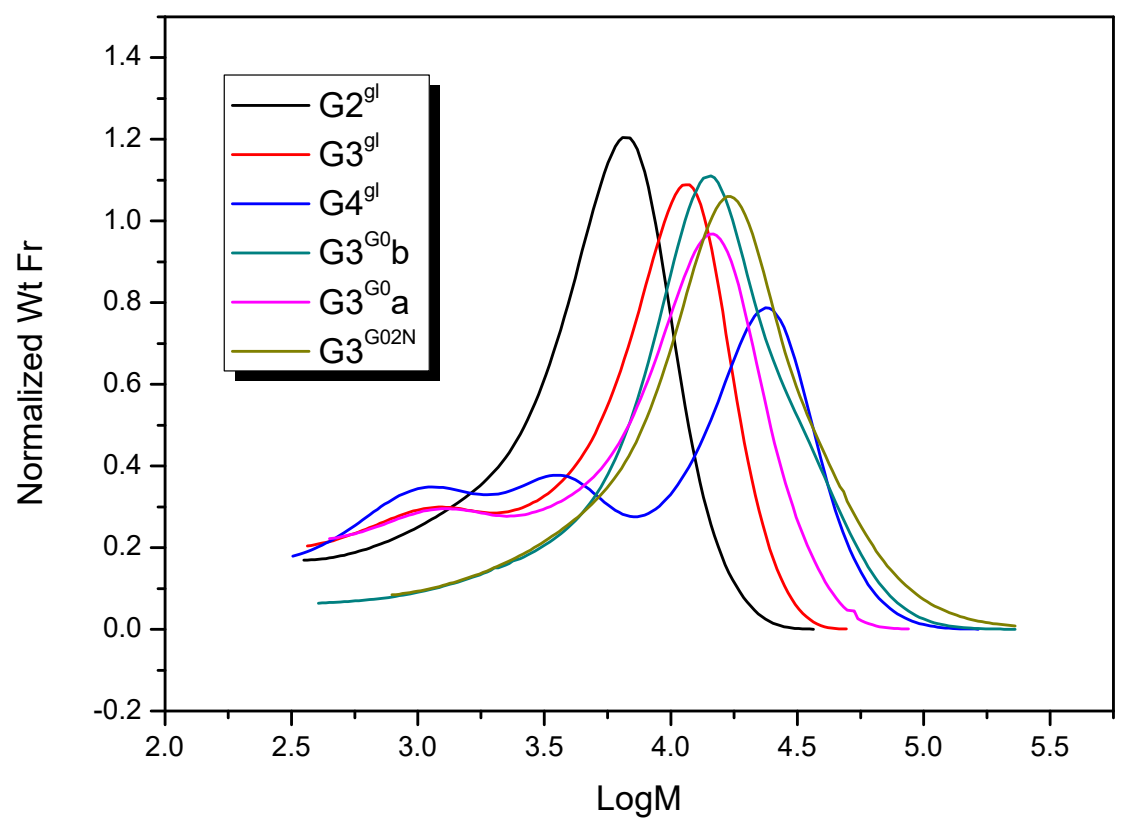

Figure A2. Molecular weight distribution curves of megamers $\mathrm{G} 3{ }^{\mathrm{G} 0}$ and $\mathrm{G} 3{ }^{\mathrm{G} 02 \mathrm{~N}}$ estimated using GPC experiments using the references obtained by reaction of PAMAM dendrimers G2, G3, and G4


2,3-dihydroxyproyl substituents and averaged molecular weight 6600,12,681, and 24,575 Da, respectively for $\mathrm{G}^{46 \mathrm{gl}}$, G3 ${ }^{78 \mathrm{gl}}$, and $\mathrm{G} 4^{140 \mathrm{gl}}$. The stoichiometry of these $\mathrm{G} 2^{\mathrm{gl}}$, G3 ${ }^{\mathrm{gl}}$, and $\mathrm{G} 4^{\mathrm{gl}}$ derivatives was determined using ${ }^{1} \mathrm{H}$ NMR spectroscopy. The ${ }^{\mathrm{gl}}{ }^{\mathrm{l}}, \mathrm{G} 3^{\mathrm{gl}}$, and $\mathrm{G} 4^{\mathrm{gl}}$ were used as molecular weight standards to determine the molecular weight of megamers. The figure represents normalized weight fraction vs $\log \mathrm{M}$ (where $\mathrm{M}$-molecular weight). Samples of megamers $\mathrm{G} 3{ }^{\mathrm{G} 0}$ a and $\mathrm{G} 3{ }^{\mathrm{G} 0} \mathrm{~b}$ were obtained from G3 $3^{64 g 1}$ : 18 NPCF : 20 G0 according to general protocol described in Experimental section. The average molecular weight of the samples $\mathrm{G}^{\mathrm{G}}{ }^{0} \mathrm{~b}$ and $\mathrm{G} 3{ }^{\mathrm{G} 0}$ a were estimated for conjugate before $(\mathrm{b})$ and after (a) dialysis. Partial loss of G0 from the conjugate upon three days extensive dialysis can be concluded from that experiment (from average 13 to 10 ).

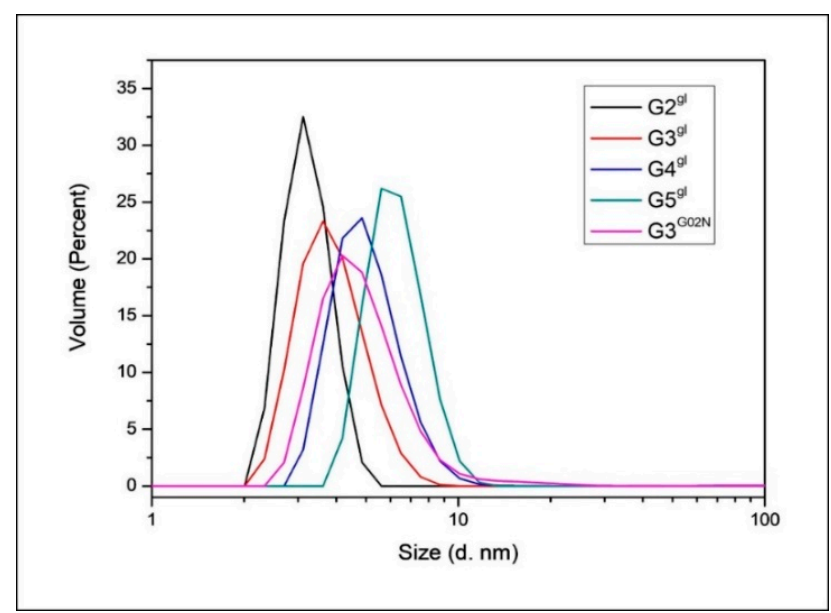

Figure A3. Size distribution of $\mathrm{GM}^{\mathrm{gl}}$ dendrimers and $\mathrm{G} 3^{\mathrm{G} 02 \mathrm{~N}}$ megamer (M-dendrimer generation). The PAMAM dendrimers coated with 2,3-dihydroxypropyl substituents were synthesized for these studies. The composition of G2 ${ }^{\mathrm{gl}}-\mathrm{G} 5^{\mathrm{gl}}$ was determined using ${ }^{1} \mathrm{H}$ NMR spectroscopy. The NMR studies on the series will be reported separately. 


\section{References}

1. Dannhardt, G.; Kiefer, W. Cyclooxygenase inhibitors-Current status and future prospects. Eur. J. Med. Chem. 2001, 36, 109-126. [CrossRef]

2. Subbaramaiah, K.; Dannenberg, A.J. Cyclooxygenase 2: A molecular target for cancer prevention and treatment. Trends Pharmcol. Sci. 2003, 24, 96-102. [CrossRef]

3. Uram, Ł.; Filipowicz, A.; Misiorek, M.; Pieńkowska, N.; Markowicz, J.; Wałajtys-Rode, E.; Wołowiec, S. Biotinylated PAMAM G3 dendrimer conjugated with celecoxib and/or Fmoc-l-Leucine and its cytotoxicity for normal and cancer human cell lines. Eur. J. Pharm. Sci. 2018, 124, 1-9. [CrossRef] [PubMed]

4. Uram, Ł.; Filipowicz-Rachwał, A.; Misiorek, M.; Winiarz, A.; Wałajtys-Rode, E.; Wołowiec, S. Synthesis and Different Effects of Biotinylated PAMAM G3 Dendrimer Substituted with Nimesulide in Human Normal Fibroblasts and Squamous Carcinoma Cells. Biomolecules 2019, 9, 437. [CrossRef]

5. Wang, W.; Xiong, W.; Zhu, Y.; Xu, H.; Yang, X. Protective effect of PEGylation against poly(amidoamine) dendrimer-induced hemolysis of human red blood cells. J. Biomed. Mater. Res. Part. B Appl. Biomater. 2010, 93, 59-64. [CrossRef] [PubMed]

6. Uram, Ł.; Szuster, M.; Filipowicz, A.; Zareba, M.; Wałajtys-Rode, E.; Wołowiec, S. Cellular uptake of glucoheptoamidated poly(amidoamine) PAMAM G3 dendrimer with amide-conjugated biotin, a potential carrier of anticancer drugs. Bioorg. Med. Chem. 2017, 25, 706-713. [CrossRef]

7. Tomalia, D.A.; Uppuluri, S.; Swanson, D.R.; Li, J. Dendrimers as reactive modules for the synthesis of new structure-controlled, higher-complexity megamers. Pure Appl. Chem. 2000, 72, 2343-2358. [CrossRef]

8. Magalhães, T.M.; Guerra, R.C.; da Silva San Gil, R.A.; Val, A.P.; Simão, R.A.; Soares, B.G.; de Carvalho Mendes, T.; dos Santos Pyrrho, A.; de Sousa, V.P.; Rodrigues-Furtado, V.L. PAMAM dendrimer hydrogel film-Biocompatible material to an efficient dermal delivery of drugs. J. Nanopart. Res. 2017, 19, 277.

9. Khopade, A.J.; Möhwald, H. Statistical Megamer Morphologies and Materials from PAMAM Dendrimers. Macromol. Rapid Commun. 2005, 26, 445-449. [CrossRef]

10. van Dongen, M.A.; Vaidyanathan, S.; Banaszak Holl, M.M. PAMAM Dendrimers as Quantized Building Blocks for Novel Nanostructures. Soft Matter 2013, 9. [CrossRef]

11. Atapour, M.H.; Mojarad, M.; Raoofian, R.; Baghebani, F.; Louie, O.; Massoudi, A.; Soukhtanloo, M.; Hooshang, V. PAMAM Megamer (G2-G2) as a versatile tool in gene delivery. Clin. Biochem. 2011, 13, S281-S282. [CrossRef]

12. Filipowicz, A.; Wołowiec, S. Bioconjugates of PAMAM dendrimers with trans-retinal, pyridoxal, and pyridoxal phosphate. Int. J. Nanomed. 2012, 7, 4819-4828.

13. Uram, Ł.; Szuster, M.; Filipowicz, A.; Gargasz, K.; Wołowiec, S.; Wałajtys-Rode, E. Different patterns of nuclear and mitochondrial penetration by the G3 PAMAM dendrimer and its biotin-pyridoxal bioconjugate BC-PAMAM in normal and cancer cells in vitro. Int. J. Nanomed. 2015, 10, 5647-5661. [CrossRef] [PubMed]

14. Czarnik, J.; Kwaśniak, K.; Tutaj, K.; Filiks, I.; Stompor, M.; Tabarkiewicz, J.; Wołowiec, S.; Uram, Ł. Glucoheptoamidated polyamidoamine PAMAM G3 dendrimer as a vehicle for succinate linked doxorubicin; enhanced toxicity of DOX against grade IV glioblastoma U-118 MG cells. J. Drug Deliv. Sci. Technol. 2019. under review.

15. Lubczak, J.; Kania, E.; Myśliwiec, B. The Kinetics and Mechanism of the Reaction between Barbituric Acid and Glycidol, Part I: The Products Analysis. Int. J. Chem. Kinet. 2017, 49, 259-266. [CrossRef]

16. Zhou, Z.; D'Emanuele, A.; Lennon, K.; Attwood, D. Synthesis and Micellization of Linear-Dendritic Copolymers and Their Solubilization Ability for Poorly Water-Soluble Drugs. Macromolecules 2009, 42, 7936-7944. [CrossRef]

17. Dupont, L.; Pirotte, B.; Masereel, B.; Delarge, J.; Geczy, J. Nimesulide. Acta Crystallogr. Sect. C 1995, 51, 507-509. [CrossRef]

18. Renard, J.-F.O.; Julémont, F.; de Leval, X.; Pirotte, B. The use of nimesulide and its analogues in cancer chemoprevention. Anticancer Agents Med. Chem. 2006, 6, 233-237. [CrossRef]

19. Zhong, B.; Cai, X.; Chennamaneni, S.; Yi, X.; Liu, L.; Pink, J.J.; Dowlati, A.; Xu, Y.; Zhou, A.; Su, B. From COX-2 inhibitor nimesulide to potent anti-cancer agent: Synthesis, in vitro, in vivo and pharmacokinetic evaluation. Eur. J. Med. Chem. 2012, 47, 432-444. [CrossRef] 
20. Najlah, M.; Freeman, S.; Attwood, D.; D’Emanuele, A. In vitro evaluation of dendrimer prodrugs for oral drug delivery. Int. J. Pharm. 2007, 336, 183-190. [CrossRef]

21. Zeng, Y.; Kurokawa, Y.; Win-Shwe, T.-T.; Zeng, Q.; Hirano, S.; Zhang, Z.; Sone, H. Effects of PAMAM dendrimers with various surface functional groups and multiple generations on cytotoxicity and neuronal differentiation using human neural progenitor cells. J. Toxicol. Sci. 2016, 41, 351-370. [CrossRef] [PubMed]

22. Uram, Ł.; Szuster, M.; Gargasz, K.; Filipowicz, A.; Wałajtys-Rode, E.; Wołowiec, S. In vitro cytotoxicity of the ternary PAMAM G3-pyridoxal-biotin bioconjugate. Int. J. Nanomed. 2013, 8, 4707-4720.

23. van der Pauw, M.T.; Van den Bos, T.; Everts, V.; Beertsen, W. Phagocytosis of fibronectin and collagens type I, III, and V by human gingival and periodontal ligament fibroblasts in vitro. J. Periodontol. 2001, 72, 1340-1347. [CrossRef] [PubMed]

24. Bronger, H.; König, J.; Kopplow, K.; Steiner, H.-H.; Ahmadi, R.; Herold-Mende, C.; Keppler, D.; Nies, A.T. $\mathrm{ABCC}$ drug efflux pumps and organic anion uptake transporters in human gliomas and the blood-tumor barrier. Cancer Res. 2005, 65, 11419-11428. [CrossRef] [PubMed]

25. Lai, P.S.; Shieh, M.-J.; Pai, C.L.; Wang, C.Y.; Lou, P.P. Studies on the Intracellular Trafficking of PAMAM Dendrimer. In Proceedings of the NSTI Nanotechnology Conference and Trade Show, Anaheim Marriott \& Convention Center, Anaheim, CA, USA, 8-12 May 2005; pp. 232-235.

26. Zhang, J.; Liu, D.; Zhang, M.; Sun, Y.; Zhang, X.; Guan, G.; Zhao, X.; Qiao, M.; Chen, D.; Hu, H. The cellular uptake mechanism, intracellular transportation, and exocytosis of polyamidoamine dendrimers in multidrug-resistant breast cancer cells. Int. J. Nanomed. 2016, 11, 3677-3690. [CrossRef] [PubMed]

27. Periasamy, J.; Muthuswami, M.; Ramesh, V.; Muthusamy, T.; Jain, A.; Karthikeyan, C.; Trivedi, P.; Kumar, R.S.; Gunasekaran, P.; Rha, S.; et al. Nimesulide and celecoxib inhibits multiple oncogenic pathways in gastric cancer cells. J. Cancer Sci. Ther. 2013, 5, 126-136. [CrossRef]

28. Hida, T.; Kozaki, K.; Muramatsu, H.; Masuda, A.; Shimizu, S.; Mitsudomi, T.; Sugiura, T.; Ogawa, M.; Takahashi, T. Cyclooxygenase-2 inhibitor induces apoptosis and enhances cytotoxicity of various anticancer agents in non-small cell lung cancer cell lines. Clin. Cancer Res. 2000, 6, 2006-2011.

29. Khodaie, F.; Khazaei-Poul, Y.; Moini-Zanjani, T. Anti-Proliferative Effects of Piroxicam and Nimesulide on A431 Human Squamous Carcinoma Cell Line. Int. J. Cancer Manag. 2017, 10. [CrossRef]

30. Parimi, S.; Barnes, T.J.; Callen, D.F.; Prestidge, C.A. Mechanistic Insight into Cell Growth, Internalization, and Cytotoxicity of PAMAM Dendrimers. Biomacromolecules 2010, 11, 382-389. [CrossRef]

31. Tomalia, D.A.; Huang, B.; Swanson, D.R.; Brothers, H.M.; Klimash, J.W. Structure control within poly(amidoamine) dendrimers: Size, shape and regio-chemical mimicry of globular proteins. Tetrahedron 2003, 59, 3799-3813. [CrossRef]

32. Uram, Ł.; Nizioł, J.; Maj, P.; Sobich, J.; Rode, W.; Ruman, T. N(4)-[B-(4,4,5,5-tetramethyl-1,3,2-dioxaborolan) methyl]-2'-deoxycytidine as a potential boron delivery agent with respect to glioblastoma. Biomed. Pharm. 2017, 95, 749-755. [CrossRef] [PubMed]

33. Sekuła, J.; Nizioł, J.; Rode, W.; Ruman, T. Gold nanoparticle-enhanced target (AuNPET) as universal solution for laser desorption/ionization mass spectrometry analysis and imaging of low molecular weight compounds. Anal. Chim. Acta 2015, 875, 61-72. [CrossRef] [PubMed]

34. CrysAlisPro, Agilent Technologies, Version 1.171.36.21t, Rigaku Oxford Diffraction (Poland): Wrocław, Poland, 2001.

35. Sheldrick, G.M. A short history of SHELX. Acta Cryst. AFound. Cryst. 2008, 64, 112-122.

(C) 2019 by the authors. Licensee MDPI, Basel, Switzerland. This article is an open access article distributed under the terms and conditions of the Creative Commons Attribution (CC BY) license (http://creativecommons.org/licenses/by/4.0/). 